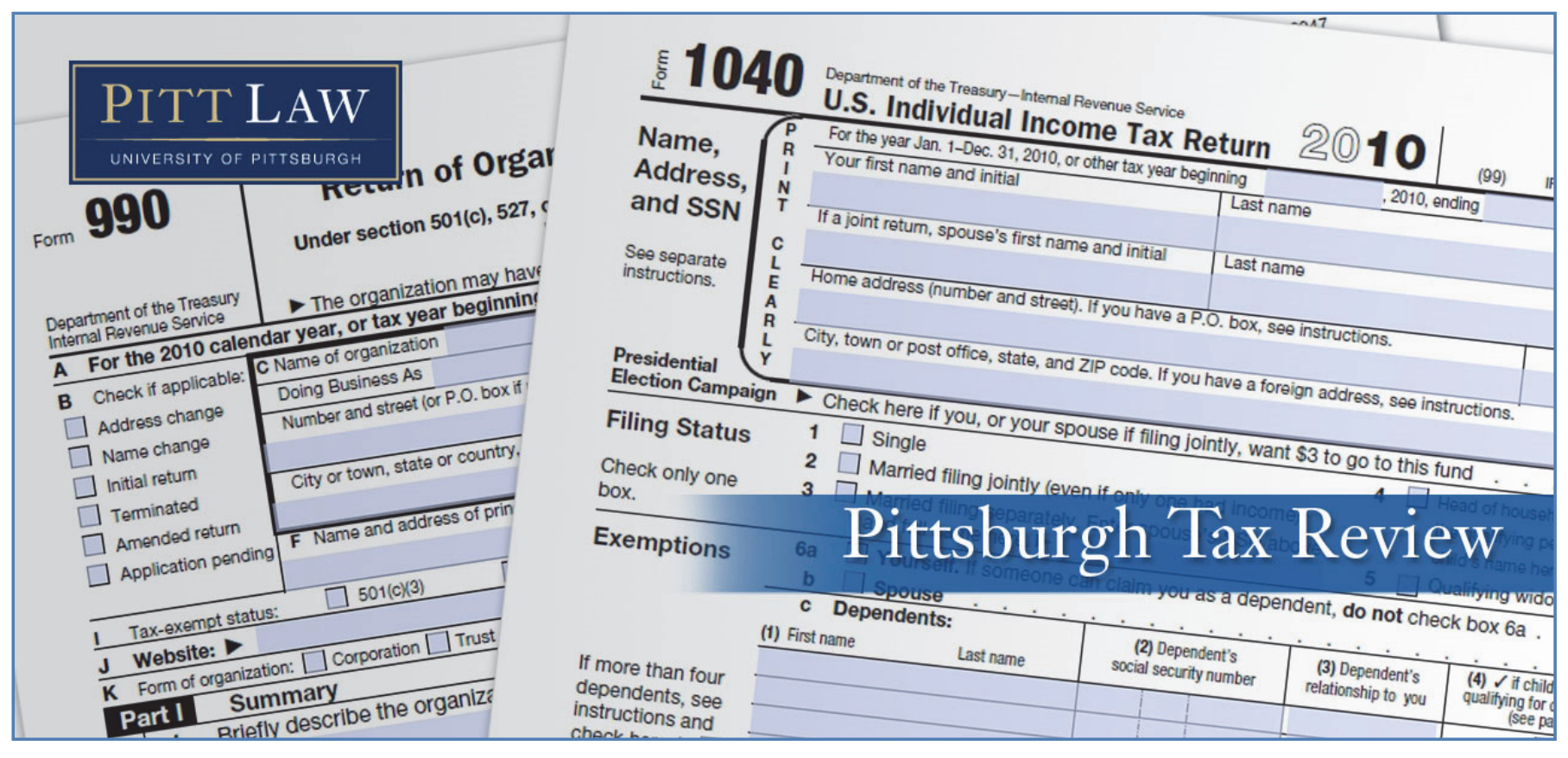

Volume 17 (2019) | ISSN 1932-1821 (print) 1932-1996 (online)

DOI 10.5195/taxreview.2019.105 | http://taxreview.law.pitt.edu

\title{
GREENBACKS FOR THE GREEN NEW DEAL
}

\author{
Tracey M. Roberts
}

\section{(c)) BY-NC-ND}

This work is licensed under a Creative Commons Attribution-Noncommercial-No Derivative Works 3.0 United States License.

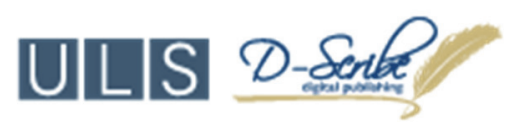

This journal is published by the University Library System of the University of Pittsburgh as part of its D-Scribe Digital Publishing Program, and is cosponsored by the University of Pittsburgh Press. 


\title{
GREENBACKS FOR THE GREEN NEW DEAL
}

\author{
Tracey M. Roberts ${ }^{*}$
}

\section{INTRODUCTION: THE GREEN NEW DEAL}

The Amazon, ${ }^{1}$ Central Africa, ${ }^{2}$ Indonesia, and Siberia are burning. ${ }^{3}$ Arctic sea ice is melting. ${ }^{4}$ Greenland, ${ }^{5}$ Iceland, ${ }^{6}$ and Antarctica ${ }^{7}$ have lost

\footnotetext{
${ }^{*}$ Assistant Professor, Samford University, Cumberland School of Law. AB Harvard College, JD Vanderbilt University Law School, LLM New York University School of Law. The author would like to thank Roberta Mann for her helpful comments and suggestions.

${ }^{1}$ Terrence McCoy, Brazil Fires: Why the Amazon Is Burning, and What It Means for Climate Change, WASH. POST (Aug. 22, 2019), https://www.washingtonpost.com/graphics/2019/world/ampstories/amazon-fires-causes-rainforest-climate-change/.

${ }^{2}$ Julie Turkewitz, The Amazon Is on Fire. So Is Central Africa., N.Y. TimES (Aug. 27, 2019), https://www.nytimes.com/2019/08/27/world/africa/congo-angola-rainforest-fires.html.

${ }^{3}$ Kendra Pierre-Louis, The Amazon, Siberia, Indonesia: A World of Fire, N.Y. TimES (Aug. 28, 2019), https://www.nytimes.com/2019/08/28/climate/fire-amazon-africa-siberia-worldwide.html.

${ }^{4}$ Sarah Kaplan, Adrift in the Arctic, WASH. POST (June 10, 2019), https://www.washingtonpost .com/graphics/2019/national/science/arctic-sea-ice-expedition-to-study-climate-change/?fbclid= IwAR0XpMDqcDF9LGoppHSqlVLmuOXnvhRGBt2bY77ZKGTNsXfe0QMPA2_rVu8\&noredirect $=$ o n; Kendra Pierre-Louis et al., Arctic Sea Ice Missed a Record Low This Winter. Barely., N.Y. TIMES (Mar. 23, 2018), https://www.nytimes.com/interactive/2018/03/23/climate/arctic-ice-maximum.html; Jeremy White \& Kendra Pierre-Louis, In the Arctic, the Old Ice Is Disappearing, N.Y. TIMES (May 14, 2018), https://www.nytimes.com/interactive/2018/05/14/climate/arctic-sea-ice.html.

${ }^{5}$ Seth Borenstein, Greenland's Glaciers Are Melting. It's as if Earth's Refrigerator Door Were Left Open, L.A. TimES (Aug. 20, 2019, 1:57 PM), https://www.latimes.com/environment/story/2019-0820/greenlands-glaciers-are-melting; Henry Fountain, Soaring Temperatures Speed Up Spring Thaw on Greenland's Ice Sheet, N.Y. TIMES (June 17, 2019), https://www.nytimes.com/2019/06/17/climate/ greenland-ice-sheet-melting.html; Mary Ilyushina \& Frederik Pleitgen, At the Bottom of a Glacier in Greenland, Climate Scientists Find Troubling Signs, CNN (Aug. 20, 2019, 1:12 AM), https://www.cnn .com/2019/08/19/weather/greenland-nasa-climate-battle-intl/index.html; John Schwartz, Greenland's Melting Ice Nears a 'Tipping Point,' Scientists Say, N.Y. TIMES (Jan. 21, 2019), https://www.nytimes .com/2019/01/21/climate/greenland-ice.html.

${ }^{6}$ Laura M. Holson, Iceland Mourns Loss of a Glacier by Posting a Warning About Climate Change, N.Y. TimeS (Aug. 19, 2019), https://www.nytimes.com/2019/08/19/world/europe/iceland-glacier-funeral .html.

${ }^{7}$ Justin Gillis, Miles of Ice Collapsing into the Sea, N.Y. TIMES (May 18, 2017), https://www .nytimes.com/interactive/2017/05/18/climate/antarctica-ice-melt-climate-change.html; Julia Jacobs,
}

Pitt Tax Review | ISSN 1932-1821 (print) 1932-1996 (online)

DOI 10.5195/taxreview.2019.105 | http://taxreview.law.pitt.edu 
glaciers at a pace far exceeding predictions under the most rigorous climate science. The oceans are warming, ${ }^{8}$ and the circulation of ocean waters has slowed. ${ }^{9}$ Climate scientists have long predicted that these changes are likely to have cascading effects ${ }^{10}$ and could lead to irreversible climate change. ${ }^{11}$

In 2018, pursuant to the Global Change Research Act of $1990,{ }^{12}$ the U.S. Global Change Research Program released a report clarifying the costs of climate inaction to the United States and its economy. ${ }^{13}$ Finally, after nearly three decades of the United States maintaining a business-as-usual course, a handful of politicians have begun campaigning for a broad federal response to climate change. In February 2019, under the leadership of Representative

Cavity in Antarctica Glacier Is Two-Thirds the Size of Manhattan, Scientists Say, N.Y. TIMES (Feb. 1, 2019), https://www.nytimes.com/2019/02/01/climate/thwaites-glacier-antarctica-cavity.html.

${ }^{8}$ Kendra Pierre-Louis, Ocean Warming Is Accelerating Faster Than Thought, New Research Finds, N.Y. TiMES (Jan. 10, 2019), https://www.nytimes.com/2019/01/10/climate/ocean-warming-climatechange.html.

${ }^{9}$ Chris Mooney, A Surprising New Picture of Ocean Circulation Could Have Major Consequences for Climate Science, WASH. Post (Jan. 31, 2019, 2:28 PM), https://www.washingtonpost.com/climateenvironment/2019/01/31/surprising-new-picture-ocean-circulation-could-have-major-consequencesclimate-science/; Chris Mooney, The Oceans' Circulation Hasn't Been This Sluggish in 1,000 years. That's Bad News., WASH. POST (Apr. 11, 2018, 1:00 PM), https://www.washingtonpost.com/news/ energy-environment/wp/2018/04/11/the-oceans-circulation-hasnt-been-this-sluggish-in-1000-years-thats -bad-news/.

${ }^{10}$ See Intergovernmental Panel on Climate Change, Global Warming OF $1.5^{\circ} \mathrm{C}$, at 247 (2018) [hereinafter IPCC $1.5^{\circ} \mathrm{C}$ ] (illustrating the growing evidence of increasing risks across a broad range of natural and human systems at $1.5^{\circ} \mathrm{C}$ and $2^{\circ} \mathrm{C}$ of global warming); see also Joel B. Smith et al., Assessing Dangerous Climate Change Through an Update of the Intergovernmental Panel on Climate Change (IPCC) "Reasons for Concern," 106 PROC. NAT’L ACAD. SCI. 4133, 4134-37 (2009).

${ }^{11}$ Coral Davenport, Major Climate Report Describes a Strong Risk of Crisis as Early as 2040, N.Y. TIMES (Oct. 7, 2018), https://www.nytimes.com/2018/10/07/climate/ipcc-climate-report-2040.html; IPCC $1.5^{\circ} \mathrm{C}$, supra note 10 , at $257,262-63,270-71,329$ (discussing regional tipping points, large-scale singular events, agricultural systems, sea ice, sea level, and forests and other ecosystems, respectively).

${ }^{12}$ See Global Change Research Act of 1990, Pub. L. No. 101-606, 104 Stat. 3096.

${ }^{13}$ See U.S. Glob. Change Research Program, Fourth National Climate Assessment (2018) (volume I presents an assessment of the physical science underlying the report and volume II assesses climate change impacts, risks, and adaptation across the United States, now and throughout the twenty-first century); Coral Davenport \& Kendra Pierre-Louis, U.S. Climate Report Warns of Damaged Environment and Shrinking Economy, N.Y. TiMES (Nov. 23, 2018), https://www.nytimes.com/2018/11/ 23/climate/us-climate-report.html.

Pitt Tax Review | ISSN 1932-1821 (print) 1932-1996 (online)

DOI 10.5195/taxreview.2019.105 | http://taxreview.law.pitt.edu 
Alexandria Ocasio-Cortez, ${ }^{14}$ the House of Representatives passed a resolution in favor of developing a Green New Deal. ${ }^{15}$

The Green New Deal resolution calls for a mobilization of federal resources over a period of ten years to achieve a number of goals: clean water, energy, transportation and manufacturing systems; pollution remediation for air, water, and soils; mitigation of and adaptation to climate change; development of sustainable agriculture; conservation of fragile and endangered ecosystems; and enhancement of biodiversity. ${ }^{16}$ The resolution calls for the federal government to: (1) prepare the country for climate change-related disasters; (2) develop clean, renewable, and zero-emission energy sources and distribution facilities; (3) repair and upgrade the water, sewer, and transportation infrastructure in the United States to reduce emissions and provide safe, efficient, affordable access; (4) transform the manufacturing sector to build, among other things, electric vehicles; (5) upgrade the built environment for water and energy efficiency and climate resilience; (6) reduce agricultural emissions and pollution, support sustainable farming and land use practices, and research and develop biological carbon sequestration; (7) restore and protect threatened, endangered, and fragile ecosystems to enhance biodiversity and support climate resilience; (8) clean up existing operational and abandoned hazardous waste sites; and (9) share expertise, technology, products, funding, and services with the international community. ${ }^{17}$

The resolution requires that these goals be achieved through fair processes that consider the effects of climate change and past inequities on vulnerable communities and others who will most be affected by these transitions. ${ }^{18}$ It also mandates structures that give these populations agency (2019).

${ }^{14}$ The Senate version of the bill was sponsored by Senator Edwin Markey. S. Res. 59, 116th Cong.

${ }^{15}$ Lisa Friedman \& Glenn Thrush, Liberal Democrats Formally Call for a "Green New Deal," Giving Substance to a Rallying Cry, N.Y. TIMES (Feb. 7, 2019), https://www.nytimes.com/2019/02/07/ climate/green-new-deal.html.

${ }^{16}$ H.R. Res. 109, 116th Cong. (2019).

${ }^{17} I d$. at $6-10$.

${ }^{18} I d$. at $5-6$.

Pitt Tax Review | ISSN 1932-1821 (print) 1932-1996 (online) DOI 10.5195/taxreview.2019.105 | http://taxreview.law.pitt.edu 
and the ability to advocate on their own behalf. ${ }^{19}$ Finally, by using the Green New Deal to create high-wage jobs and to counteract systemic injustices, the resolution's proponents seek to ensure that the United States will enjoy affordable, high-quality healthcare, housing, food, and economic security, and access to clean water, air, and natural environments. ${ }^{20}$

While the Republican-led Senate subsequently voted against the resolution, ${ }^{21}$ public support for federal action to address climate change has surged. ${ }^{22}$ Furthermore, polls suggest that people actually like the Green New Deal. ${ }^{23}$

The House resolution set forth a framework, but it did not include any details about programs that would be implemented to achieve the Green New Deal goals. ${ }^{24}$ A recently formed think tank, New Consensus, ${ }^{25}$ has been charged with the responsibility of assembling a detailed plan, ${ }^{26}$ but to date it

${ }^{19} I d$. at $12-13$ (providing for (1) transparent, inclusive, democratic, and participatory processes that take into account the rights of citizens, vulnerable communities, impacted workers, and indigenous communities and that account for the environmental and social costs and impacts of environmental harms; (2) diversified economic development, training, education, advancement, and job creation with guaranteed family-sustaining wage, benefit, and retirement security programs for those communities; and (3) legal protections to empower workers to advocate on their own behalf, trade laws that take into account environmental and labor protections, and prevent unfair competition and the exercise of market power).

${ }^{20} I d$. at 14

${ }^{21}$ Dino Grandoni \& Felicia Sonmez, Senate Defeats Green New Deal, as Democrats Call Vote a "Sham," WASH. POST (Mar. 26, 2019, 5:27 PM), https://www.washingtonpost.com/powerpost/greennew-deal-on-track-to-senate-defeat-as-democrats-call-vote-a-sham/2019/03/26/834f3e5e-4fdd-11e9a3f7-78b7525a8d5f_story.html.

${ }^{22}$ See Energy Policy Inst. at Univ. of Chicago \& AP-NORC Ctr. for Pub. Affairs Research, Is the Public Willing to Pay to Help Fix Climate Change? (2019), http://www.apnorc.org/projects/Documents/ EPIC\%20fact\%20sheet_v4_DTP.pdf. Polls conducted in November 2018 indicate that seventy-one percent of Americans agree that climate change is occurring. Of those, eighty-three percent are in favor of government action to address the problem. $I d$. at 1.

${ }^{23}$ Sean McElwee, Opinion, People Actually Like the Green New Deal, N.Y. TIMES (Mar. 27, 2019), https://www.nytimes.com/2019/03/27/opinion/sunday/green-new-deal-mcconnell.html (discussing national polling data about the Green New Deal).

${ }^{24}$ See H.R. Res. 109, 116th Cong. (2019).

${ }^{25}$ NEW CONSENSUS, https://newconsensus.com/ (last visited Dec. 23, 2019).

${ }^{26}$ Robinson Meyer, The Think Tank Struggling to Write the Green New Deal, ATLANTIC (June 12, 2019), https://www.theatlantic.com/science/archive/2019/06/whats-green-new-deal-nobody-knows/ $591391 \%$.

Pitt Tax Review | ISSN 1932-1821 (print) 1932-1996 (online)

DOI 10.5195/taxreview.2019.105 | http://taxreview.law.pitt.edu 
has provided very little information. ${ }^{27}$ Nevertheless, assorted advisors have begun to discuss ways to structure the plan for political success, ${ }^{28}$ and environmental experts have offered guidance about features likely to procure desired outcomes. ${ }^{29}$

In addition, the leading Democratic presidential candidates have embraced the Green New Deal and included climate change plans as part of their platforms. While some candidates have gone so far as to identify funding sources for their climate plans, and some have indicated that they plan to use federal funds as leverage to encourage private, state, and local investment, discussions about the mechanisms for doing so have been fairly limited.

This Article is designed to address the gap between the candidates' Green New Deal goals, plans, funding sources, and financing mechanisms. Part II describes the candidates' plans for transforming the nation's economy, including any new taxes or other measures they are considering to provide resources for in their programs. Part III explains why private markets fail to address problems like climate change and evaluates the candidates' plans to address carbon emissions and remediate other pollutants. Part IV contextualizes Green New Deal plans to overhaul the nation's infrastructure and protect its ecosystems, explaining why private markets fail to undertake these types of important projects. It describes the types of measures that the federal government has deployed historically to develop infrastructure and preserve habitat and examines the successes and shortcomings of these

${ }^{27}$ See Rhiana Gunn-Wright \& Robert Hockett, New ConSENSUS, The Green New Deal: Mobilizing for a Just, Prosperous, and Sustainable Economy (2019).

${ }^{28}$ See, e.g., Neil M. Maher, The Keys to Ensuring That a Green New Deal Succeeds, WASH. POST (Aug. 7, 2019, 6:00 AM), https://www.washingtonpost.com/outlook/2019/08/07/flaw-all-democratsgreen-new-deal-proposals/ (arguing in favor of a ground-up approach, similar to the New Deal's Soil Conservation Service, Tennessee Valley Authority, and the Civilian Conservation Corps programs, that gives local communities a vested political and economic stake in improving carbon emissions).

${ }^{29}$ See, e.g., Michael Burger, Five Legal Principles for the Green New Deal, WASH. POST (May 22, 2019, 6:00 AM), https://www.washingtonpost.com/outlook/2019/05/22/five-legal-principles-green-newdeal/ (arguing that the Green New Deal must be passed as legislation, because the executive and judicial branches lack the power to affect systemic change, and specifying that the legislation should: (i) be comprehensive in scope; (ii) identify specific programs for achieving net-zero carbon emissions by 2050; (iii) contain deadlines for compliance; (iv) include citizen-suit enforcement provisions; and (v) set federal floors for compliance, but grant states the authority to innovate and exceed national standards).

Pitt Tax Review | ISSN 1932-1821 (print) 1932-1996 (online) DOI 10.5195/taxreview.2019.105 | http://taxreview.law.pitt.edu 
measures, providing guidance for the candidates' plans. Finally, it concludes by identifying the structures that are likely to lead to equitable, as well as efficient, outcomes as the United States moves toward a greener, safer, and more prosperous future.

\section{The CANDidATES' Climate Proposals}

In general, the Democratic presidential candidates' proposals for climate change are varied and innovative. Mayor Pete Buttigieg ${ }^{30}$ has provided the least detail about his climate plan, but his proposal is likely to be the most efficient. Buttigieg plans to enact a carbon tax-and-dividend program. ${ }^{31}$ A tax-and-dividend program imposes a Pigouvian tax on a pollutant and then transfers some or all of the tax revenues to the public. ${ }^{32} \mathrm{~A}$ carbon tax, by increasing the price of fossil fuel energy sources to reflect the costs of their pollution, will increase the price of goods and services manufactured or distributed using fossil fuel energy, deter excess energy consumption, and encourage the use of clean energy as a substitute. ${ }^{33}$ The "dividend" is likely to be a lump sum rebate designed to offset the financial impacts of the tax, particularly for low- and middle-income households. ${ }^{34}$ If designed correctly, the dividend will not undermine the efficiency-enhancing effects of the carbon tax and will provide an equitable distribution of the tax proceeds. ${ }^{35}$ While Buttigieg has not clarified the size of the rebates or how

${ }^{30}$ Pete Buttigieg, Issues: It's Time to Reclaim the Values That Drive Our Policy Decisions, PeTE 2020, https://peteforamerica.com/issues/ (last visited Dec. 2, 2019) [hereinafter Buttigieg Plan].

${ }^{31} \mathrm{Id}$.

${ }^{32}$ See Shi-Ling Hsu, A Complete Analysis of Carbon Taxation: Considering the Revenue Side, 65 Buff. L. Rev. 857, 866, 887-91 (2017); Carbon Fee and Dividend Policy, Citizens' Climate LobBy, https://citizensclimatelobby.org/carbon-fee-and-dividend/ (last visited Dec. 23, 2019).

${ }^{33}$ Shi-Ling Hsu, The Case for a Carbon Tax: Getting Past Our Hang-ups to EfFective Climate Policy 65-66 (2d ed. 2011).

${ }^{34}$ See The Four Pillars of Our Carbon Dividends Plan, Climate Leadership Council, https://www.clcouncil.org/our-plan/ (last visited Dec. 23, 2019) (describing a carbon tax and dividend plan that would deliver payment of the carbon tax revenues for each household; the payment would be made on a quarterly basis via dividend checks, direct deposits, or contributions to individual retirement accounts).

${ }^{35}$ Stephie Fried et al., The Green Dividend Dilemma: Carbon Dividends Versus Double-Dividends, BD. GOVERNORS FED. RES. (Mar. 8, 2019), https://www.federalreserve.gov/econres/notes/fedsnotes/green-dividend-dilemma-carbon-dividends-versus-double-dividends-20190308.htm. There are other options that may enhance the efficiency of the U.S. tax system. See Hsu, supra note 32, at 866

Pitt Tax Review | ISSN 1932-1821 (print) 1932-1996 (online)

DOI 10.5195/taxreview.2019.105 | http://taxreview.law.pitt.edu 
they will be distributed, he has indicated that he also plans to use "major direct investment to build a 100 percent clean energy society," multiplying federal research and development funding for renewable energy and energy storage. ${ }^{36} \mathrm{He}$ has not identified other sources of funds for that investment, so presumably the carbon tax revenues may be the source. ${ }^{37}$

Senator Elizabeth Warren's climate change proposals are set forth in a series of news articles to which her campaign website has linked. ${ }^{38}$ To address emissions, she plans to reinstate the Clean Power Plan, the command and control regime under the Clean Air Act that places limits on carbon dioxide emissions and asks states to develop plans to achieve those goals. ${ }^{39}$ Under her leadership, the United States would also maintain its commitments under the Paris Agreement, which set emissions targets for signatory countries. ${ }^{40}$ She would accelerate compliance with national and international goals through new securities filing provisions that will require publicly traded companies to disclose the climate change risks to their businesses from

(discussing the various alternatives for use of carbon tax proceeds). However, they would do so at either a reduction in the effectiveness of the carbon tax (by doing such things as lowering the gas tax) or at the cost of fairness. Some plans to use the tax revenues to reduce income or payroll taxes would not reach households relying on Social Security or disability payments and would not necessarily track the impacts of the carbon tax on most households. See Tracey M. Roberts, Mitigating the Distributional Impacts of Climate Change Policy, 67 WASH. \& LEE L. REV. 209, 240-58 (2010).

${ }^{36}$ Buttigieg Plan, supra note 30.

${ }^{37} \mathrm{Id}$.

${ }^{38}$ Elizabeth Warren, Tackling the Climate Crisis Head On, WARREN, https://elizabethwarren.com/ plans/climate-change (last visited Dec. 23, 2019) [hereinafter Warren Plan]. She has recently adopted the climate proposals of former presidential candidate Jay Inslee. Coral Davenport \& Lisa Friedman, Elizabeth Warren Unveils Climate Change Plan, Embracing Jay Inslee's Goals, N.Y. TIMES (Sept. 3, 2019), https://www.nytimes.com/2019/09/03/us/politics/elizabeth-warren-climate-change-plan.html.

${ }^{39}$ Elizabeth Warren, Accelerating the Transition to Clean Energy, Medium (July 10, 2019), https://medium.com/@teamwarren/accelerating-the-transition-to-clean-energy-46af492d8c57. But see Coral Davenport \& Trip Gabriel, Climate Town Hall: Several Democratic Candidates Embrace a Carbon Tax, N.Y. TIMES (Sept. 4, 2019), https://www.nytimes.com/2019/09/04/us/politics/democrats-climatechange-plans.html (discussing Warren's support of a carbon tax during a $\mathrm{CNN}$ forum on climate change).

${ }^{40}$ Warren, supra note 39. On June 1, 2017, President Trump announced that the United States would withdraw from the Paris Climate Agreement. Michael D. Shear, Trump Will Withdraw U.S. From Paris Climate Agreement, N.Y. TIMES (June 1, 2017), https://www.nytimes.com/2017/06/01/climate/ trump-paris-climate-agreement.html. Under article 28 of the agreement, the first date the United States may actually withdraw is November 4, 2020. Paris Agreement to the United Nations Framework Convention on Climate Change, Dec. 12, 2015, T.I.A.S. No. 16-1104.

Pitt Tax Review | ISSN 1932-1821 (print) 1932-1996 (online) DOI 10.5195/taxreview.2019.105 | http://taxreview.law.pitt.edu 
both continuing unchecked emissions under current policies, and, in the alternative, from adhering to greenhouse gas targets under the Paris Agreement. $^{41}$

Warren's most audacious plan calls for a return to industrial policy. ${ }^{42}$ She plans to transform the American economy through (1) a $\$ 400$ billion investment, over ten years, in research through the creation of a National Institute of Clean Energy; (2) a $\$ 1.5$ trillion federal procurement program (\$150 billion per year over ten years) to encourage the development of and demand for clean, renewable, and emissions-free energy, infrastructure, and building technologies, a portion of which will be funded by existing Department of Defense budgetary allocations; ${ }^{43}$ (3) a $\$ 100$ billion "Green Marshall Plan," in which the United States provides loans to foreign countries to purchase American-made green energy, infrastructure, transportation, and manufacturing technologies; ${ }^{44}$ and (4) a $\$ 1$ trillion investment over ten years to subsidize the economic transition to clean and

${ }^{41}$ Warren, supra note 39.

${ }^{42}$ See Robinson Meyer, A Centuries-Old Idea Could Revolutionize Climate Policy, ATLANTIC (Feb. 19, 2019), https://www.theatlantic.com/science/archive/2019/02/green-new-deal-economicprinciples/582943/; Elizabeth Warren, My Green Manufacturing Plan for America, Medium (June 4, 2019), https://medium.com/@teamwarren/my-green-manufacturing-plan-for-america-fc0ad53ab614 (recalling the transformational effort and funding that went into mobilizing an industrial base for World War II (calling now for a Green Industrial Mobilization), the post-World War II expansion of American influence and trade partnerships (calling now for a Green Marshall Plan), and leading the space race during the Cold War (calling now for a Green Apollo Program)); see also Katy Lederer, Meet the Leftish Economist with a New Story About Capitalism, N.Y. TIMES (Nov. 26, 2019), https://www.nytimes.com/ 2019/11/26/business/mariana-mazzucato.html ("In two books of modern political economic theory-'The Entrepreneurial State' (2013) and 'The Value of Everything' (2018) —Dr. Mazzucato argues against the long-accepted binary of an agile private sector and a lumbering, inefficient state. Citing markets and technologies like the internet, the iPhone and clean energy - all of which were funded at crucial stages by public dollars - she says the state has been an underappreciated driver of growth and innovation. ... Her message has appealed to an array of American politicians. Senator Elizabeth Warren, Democrat of Massachusetts and a presidential contender, has incorporated Dr. Mazzucato's thinking into several policy rollouts, including one that would use 'federal R \& D to create domestic jobs and sustainable investments in the future' and another that would authorize the government to receive a return on its investments in the pharmaceutical industry.").

${ }^{43}$ See Elizabeth Warren, Our Military Can Help Lead the Fight in Combating Climate Change, MEDIUM (May 15, 2019), https://medium.com/@teamwarren/our-military-can-help-lead-the-fight-incombating-climate-change-2955003555a3; see also Warren, supra note 42.

${ }^{44}$ Warren, supra note 42 (noting that the United States currently subsidizes arms sales to foreign countries to support U.S. defense contractors and suggests that these tools and subsidies could be reallocated to address climate change and to help a broader segment of the economy).

Pitt Tax Review | ISSN 1932-1821 (print) 1932-1996 (online)

DOI 10.5195/taxreview.2019.105 | http://taxreview.law.pitt.edu 
renewable energy, transportation (focusing on zero-emission vehicles), and building design and construction. ${ }^{45}$ She plans to impose a moratorium on all new fossil fuel leases, including off-shore drilling on public lands and marine areas and to use those lands to generate ten percent of the country's energy demands with solar, wind, and geothermal projects. ${ }^{46}$ Through an expansion of the Conservation Stewardship Program, she plans to compensate farmers for employing sustainable agriculture practices. ${ }^{47}$ She plans to fund her program by ending federal oil and gas subsidies, and through a new "Real Corporate Profits Tax." ${ }^{, 8}$ The Real Corporate Profits Tax is a seven percent excise tax levied on corporate profits exceeding $\$ 100$ million. ${ }^{49}$ The tax would not be levied against corporate earnings and profits measured under the current corporate income tax, but against profits reported under the financial accounting rules. ${ }^{50}$ She appears to plan to limit corporate tax avoidance with new restrictions on inversions and other overseas transfers. ${ }^{51}$

University of California, Berkley economists Emmanuel Saez and Gabriel Zucman report that Warren's corporate excise tax should generate $\$ 1.05$ trillion in revenues over the ten-year period. ${ }^{52}$ The chief economist at

\footnotetext{
${ }^{45}$ Elizabeth Warren, 100\% Clean Energy for America, MEDIUM (Sept. 3, 2019), https://medium .com/@teamwarren/100-clean-energy-for-america-de75ee39887d.

${ }^{46}$ Elizabeth Warren, My Plan for Public Lands, Medium (Apr. 15, 2019), https://medium.com/ @teamwarren/my-plan-for-public-lands-e4be1d88a01c.

${ }^{47}$ Miranda Green, Warren Would Pay Farmers to Fight Climate Change Under New Plan, HiLL (Aug. 7, 2019, 12:04 PM), https://thehill.com/policy/energy-environment/456547-warren-to-pay-farmers -to-fight-climate-change-under-new-plan.

${ }^{48}$ Warren, supra note 42.

${ }^{49}$ Elizabeth Warren, I'm Proposing a Big New Idea: The Real Corporate Profits Tax, MEdIUM (Apr. 11, 2019), https://medium.com/@teamwarren/im-proposing-a-big-new-idea-the-real-corporateprofits-tax-29dde7c960d.

${ }^{50} I d$. Warren's article does not evaluate Warren's Real Corporate Income Tax proposal. However, several scholars and government agencies have considered the benefits of reconciling the disparities between tax accounting and financial accounting more generally. See, e.g., Maria Theresia Evers et al., The Implications of Book-Tax Differences: A Meta-Analysis (ZEW Discussion Paper No. 17-003, 2016).

${ }^{51}$ Warren, supra note 42 (stating that she will be "closing corporate tax loopholes that promote moving good jobs overseas").

${ }^{52}$ Letter from Emmanuel Saez \& Gabriel Zucman, Professors of Econ., Univ. of Cal., Berkeley, to Senator Elizabeth Warren (Apr. 8, 2019), https://elizabethwarren.com/wp-content/uploads/2019/04/Saezand-Zucman-Letter-on-Real-Corporate-Profits-Tax-4.10.19-2.pdf ("We estimate that close to 1,200 public corporations would be liable for this tax and that it would raise $\$ 1.05$ trillion on public companies
}

Pitt Tax Review | ISSN 1932-1821 (print) 1932-1996 (online) DOI 10.5195/taxreview.2019.105 | http://taxreview.law.pitt.edu 
Moody's Analytics, Mark Zandi, examined her climate plan. ${ }^{53}$ He estimates that the Real Corporate Income Tax, when combined with the other tax changes described above, would offset $\$ 1.3$ trillion of the $\$ 2$ trillion ten-year cost, leaving a net static cost of $\$ 700$ billion to be covered by other sources. ${ }^{54}$ He notes that when the ten-year dynamic economic effects of her programs are taken into account, the net cost of those programs would be limited to $\$ 100$ billion. $^{55}$

Presidential candidate Joe Biden plans a federal outlay of $\$ 1.7$ trillion to cover his climate change plan. ${ }^{56}$ Biden's plan is fairly general and shares a number of common elements with Senator Warren's plan. ${ }^{57}$ For example, like Warren, Biden plans to implement climate change regulation under the Clean Air Act. ${ }^{58}$ However, unlike Warren and other candidates, he plans to require net-zero emissions by 2050 instead of 2030; he supports nuclear

alone over the ten-year budget window 2019-2028. Our estimates only include public corporations (for which data is readily available) and should thus be seen as lower bounds. This tax would increase federal corporation income tax receipts from the projected $\$ 256$ billion for fiscal year 2020 to about $\$ 340$ billion."); Aída Chávez, Elizabeth Warren Has a Novel Idea: Tax Corporations on the Profits They Claim Publicly, INTERCEPT (Apr. 11 2019, 11:00 AM), https://theintercept.com/2019/04/11/elizabeth-warrenhas-a-novel-idea-tax-corporations-on-the-profits-they-claim-publicly.

${ }^{53}$ Mark Zandi, Moody's Analytics, The Macroeconomic Impact of Senator Warren's ClEAN ENERGY PLAN (2019) (excluding analysis of Warren's new \$1 trillion investment in clean energy, announced on September 3, 2019, which she says will be funded by eliminating the corporate tax cuts under the Tax Cuts and Jobs Act of 2017).

${ }^{54} I d$. at 2.

${ }^{55} \mathrm{Id}$. ("According to an outside analysis, this tax would generate $\$ 1.05$ trillion in additional revenues over the next decade. Some $\$ 100$ billion in 10 -year revenues would be generated by eliminating various tax subsidies to the oil and gas industries, and an additional $\$ 150$ billion in 10-year revenues would be raised by adopting legislation to close corporate tax loopholes created by the Tax Cut and Jobs Act, which promotes offshoring by U.S. companies .... Senator Warren's clean energy plan thus results in a static increase in the federal budget deficit of $\$ 700$ billion over the next decade. The dynamic increase in the 10-year budget deficit-after accounting for the benefit of the stronger economy on government spending and revenues - is estimated at just over $\$ 100$ billion.").

${ }^{56}$ Joe Biden, Climate: Joe's Plan for a Clean Energy Revolution and Environmental Justice, BIDEN PRESIDENT, https://joebiden.com/climate/ [hereinafter Biden Plan]; Eric Bradner \& Arlette Saenz, Joe Biden's Climate Plan Targets Net-Zero Emissions by 2050, CNN (June 4, 2019, 11:48 AM), https://www.cnn.com/2019/06/04/politics/joe-biden-2020-climate-plan/index.html.

${ }^{57}$ Biden Plan, supra note 56.

${ }^{58} \mathrm{Id}$.

Pitt Tax Review | ISSN 1932-1821 (print) 1932-1996 (online)

DOI 10.5195/taxreview.2019.105 | http://taxreview.law.pitt.edu 
energy as a zero-emissions fuel ${ }^{.59}$ and he plans to increase tax support for developing carbon capture and storage. ${ }^{60}$ Like Warren, he also plans investment in research and innovation that he likens to the Apollo space mission, and wants to use the government procurement system to encourage the development of clean energy and zero-emissions vehicles, building systems, and facilities. ${ }^{61}$ Similar to Warren, he proposes to require public companies to disclose their climate risks. ${ }^{62}$ Unlike other candidates, he initiates his plan with a focus on climate change as a global collective action problem. ${ }^{63}$ He expresses concern that all nations should do their part to address climate change and he states that he plans to use U.S. trade, foreign policy, and national security strategies to pressure other countries to adhere to their Paris Agreement commitments. ${ }^{64}$

Biden plans to fund his proposal by reversing a portion of the 2017 corporate tax cuts; $;{ }^{65}$ by eliminating fossil fuel subsidies; by changing existing incentives to shelter revenues in foreign tax havens; and possibly, by revising capital gains preferences or strengthening the estate and gift tax regime ${ }^{66} \mathrm{He}$ also plans to leverage federal funds to secure an additional $\$ 3.3$ trillion in

${ }^{59} \mathrm{Id}$.

${ }^{60} \mathrm{Id}$. Carbon capture and storage has been slow to reach a functional implementation stage. See Jason Daley, Major "Clean Coal" Project in Mississippi Shuts Down, SMithSonian (July 3, 2017), https://www.smithsonianmag.com/smart-news/major-clean-coal-project-mississippi-shut-down180963898/\#u5fmcbrux27bobE1.99 (describing the Public Service Commission decision to shut down a carbon capture and storage project that was three years behind schedule and more than $\$ 4$ billion over its initial budget of $\$ 2.9$ billion).

${ }^{61}$ Biden Plan, supra note 56.

${ }^{62}$ See id.

${ }^{63} \mathrm{Id}$.

${ }^{64} \mathrm{Id}$.

${ }^{65}$ See Tax Cuts and Jobs Act, Pub. L. No. 115-97, 131 Stat. 2054 (2017).

${ }^{66}$ Biden Plan, supra note 56 (calling for "closing other loopholes in our tax code that reward wealth not work").

Pitt Tax Review | ISSN 1932-1821 (print) 1932-1996 (online) DOI 10.5195/taxreview.2019.105 | http://taxreview.law.pitt.edu 
private investment and state and local financial support, but he does not identify the mechanisms he will use to accomplish this. ${ }^{67}$

Senator Bernie Sanders's Green New Deal plan is the most expansive and ambitious of the four. Sanders calls for $\$ 16.3$ trillion in public investment over ten years. ${ }^{68} \mathrm{He}$ claims that the plan will pay for itself over fifteen years, based on the review of experts who have scored the budgetary impacts. ${ }^{69} \mathrm{He}$ argues that various parts of the climate plan will increase revenues, but he suggests that increased corporate and estate taxes, as well as the savings from a smaller military will supplement those revenues to pay for his plan. ${ }^{70}$ Over nearly forty pages, Sanders fleshes out his climate plan with a greater level of detail than the other candidates. ${ }^{71}$ While the current version of the plan is somewhat repetitive and disorganized, the main foci appear to be: (1) shifting to $100 \%$ renewable energy systems, and improving related transportation, water, and manufacturing infrastructure; (2) requiring polluters to pay and limiting their capacity to pollute further; (3) ramping up conservation, climate adaptation, and resilience-building efforts; and (4) extending the benefits of these transformational changes to communities historically harmed. ${ }^{72}$

To transform the energy sector, Sanders would impose a federal renewable energy standard and spend $\$ 1.52$ trillion to build wind, solar, and geothermal plants; $\$ 852$ billion to develop energy storage systems; and $\$ 526$ billion to construct smart grid distribution facilities. ${ }^{73}$ Taking a page from President Franklin D. Roosevelt's New Deal, the energy from these facilities

\footnotetext{
${ }^{67}$ Id. Note that the Paris Agreement generally lacks enforcement provisions. The Paris Agreement: Frequently Asked Questions, UNITED NATIONS, https://www.un.org/sustainabledevelopment/blog/2016/ 09/the-paris-agreement-faqs/ (last visited Dec. 23, 2019).

${ }^{68}$ See Bernie Sanders, The Green New Deal, BERNIE, https://berniesanders.com/issues/the-greennew-deal/ (last visited Dec. 23, 2019) [hereinafter Sanders Plan].

${ }^{69} I d$.

${ }^{70}$ See id. Sanders argues that energy independence will generate substantial defense savings, since the military needed to protect oil access will be much smaller.

${ }^{71}$ Lisa Friedman, Bernie Sanders's “Green New Deal”: A \$16 Trillion Climate Plan, N.Y. TIMES (Aug. 22, 2019), https://www.nytimes.com/2019/08/22/climate/bernie-sanders-climate-change.html.

${ }^{72}$ Sanders Plan, supra note 68.

${ }^{73} \mathrm{Id}$.
}

Pitt Tax Review | ISSN 1932-1821 (print) 1932-1996 (online) DOI 10.5195/taxreview.2019.105 | http://taxreview.law.pitt.edu 
would be owned by the four existing and one newly developed Power Marketing Administrations, the Bureau of Reclamation, and the Tennessee Valley Authority, who would sell electricity at wholesale rates to distribution utilities. ${ }^{74}$ These wholesale energy sales would cover the costs of constructing the facilities over fifteen years, after which the energy would be produced at zero cost, except for facility operations and maintenance. ${ }^{75}$

To reduce energy demand, he plans to address existing problems with the built environment. He plans to mandate the retrofit of commercial buildings and homes for energy efficiency, to offer $\$ 2.18$ trillion in grants to small businesses and low- to moderate-income households to weatherize, and to replace all mobile homes with zero-energy modular homes. ${ }^{76} \mathrm{He}$ plans to provide $\$ 964$ billion in sliding scale grants to eliminate oil, propane, and natural gas heating and cooking units. ${ }^{77} \mathrm{He}$ will further enhance housing stock by improving public water resources, extending broadband internet access, and improving affordable housing options. ${ }^{78}$

Sanders plans to revamp U.S. transportation systems by funding $\$ 300$ billion in public transit improvements and $\$ 607$ billion in regional high-speed passenger and cargo rail. ${ }^{79}$ Another $\$ 2.09$ trillion would go toward shifting the transportation sector from conventional combustion engines to electric vehicles, with $\$ 85.6$ billion for refueling infrastructure, $\$ 681$ billion for grants to low- and middle-income households and small businesses to encourage the acquisition and trade-in of older cars for electric vehicles, $\$ 407$ billion to replace school and transit buses, $\$ 216$ billion to replace diesel tractor trailers for shipping. ${ }^{80}$ He plans to spend significant research and development funds for energy storage, technology to decarbonize industry

\footnotetext{
${ }^{74} \mathrm{Id}$.

${ }^{75} \mathrm{Id}$.

${ }^{76} I d$. A Department of Energy mandate would require other homeowners and larger businesses to make their buildings energy efficient.

${ }^{77} \mathrm{Id}$.

${ }^{78} I d$.

${ }^{79} \mathrm{Id}$.

${ }^{80} \mathrm{Id}$.
}

Pitt Tax Review | ISSN 1932-1821 (print) 1932-1996 (online) DOI 10.5195/taxreview.2019.105 | http://taxreview.law.pitt.edu 
and aviation, and a nationwide recycling program. ${ }^{81} \mathrm{He}$ also plans $\$ 636.1$ billion for reconstruction of roads, bridges, and water infrastructure with an additional $\$ 300$ billion to support climate resilience. ${ }^{82}$ Sanders anticipates that the changing energy, transportation, and manufacturing sectors will create new jobs, increasing income tax revenues and reducing reliance on the social safety net. ${ }^{83}$ These new revenues and budgetary savings would cover part of his program's cost. ${ }^{84}$

The Land and Water Conservation Fund would receive full budgetary allocations to increase conservation efforts. ${ }^{85} \mathrm{He}$ would reinstate the Civilian Conservation Corps to plant trees, maintain trails, restore national parks, repair and construct green infrastructure, and restore wetlands and coral reefs to prevent flooding and slow erosion. ${ }^{86} \mathrm{He}$ plans to rebuild other U.S. infrastructure to improve climate resilience, including $\$ 162$ billion for coastal adaptation. ${ }^{87}$

Sanders plans to regulate all greenhouse gases under the Clean Air Act, including carbon dioxide, methane, and chlorofluorocarbons ${ }^{88}$ He will end all subsidies for fossil fuels, ${ }^{89}$ institute a polluter pays principle by instituting litigation against the fossil fuel industry for their knowing contributions to climate change, raise taxes on fossil fuel income and wealth, and increase

${ }^{81} I d$.

${ }^{82} I d$.

${ }^{83} \mathrm{Id}$.

${ }^{84} \mathrm{Id}$.

${ }^{85}$ Id. The Land and Water Conservation Fund Act of 1965 directs the $\$ 900$ million in annual royalties from federal oil and gas leases on the outer continental shelf to a special account for conservation and recreation projects, though in most years Congress has diverted the majority of funds to other purposes. See also Land and Water Conservation Fund, U.S. DEP'T INTERIOR, https://www.doi.gov/ lwcf/about/overview (last visited Dec. 23, 2019).

${ }^{86}$ Sanders Plan, supra note 68 . Warren's April 15 release of her plan for public lands included a similar proposal with fewer details. See Warren, supra note 46.

${ }^{87}$ Sanders Plan, supra note 68.

${ }^{88} \mathrm{Id}$.

${ }^{89}$ Id. In 2015 Senator Sanders introduced a comprehensive bill to eliminate tax subsidies to the fossil fuel industry. See End Polluter Welfare Act, S. 1041, 114th Cong. (2015). Minnesota Representative Keith Ellison joined him in this effort. See id.

Pitt Tax Review | ISSN 1932-1821 (print) 1932-1996 (online) DOI 10.5195/taxreview.2019.105 | http://taxreview.law.pitt.edu 
penalties on pollution. ${ }^{90} \mathrm{He}$ plans to require owners of fossil fuel infrastructure to insure their risks by purchasing bonds to cover the costs of natural and other disasters. He plans to deprive fossil fuel industry of new investment by (1) ending U.S. funding of fossil fuels via the World Bank, the International Monetary fund, the Overseas Private Investment Corporation, the Export-Import Bank, and other multilateral institutions; (2) encouraging large institutional investors to replace their fossil fuel portfolios with clean energy bonds; and (3) requiring federal pensions to divest. ${ }^{91} \mathrm{He}$ further ratchets down investment in fossil fuels by terminating permits for extraction, transportation, and storage infrastructure. ${ }^{92}$ He plans to ban a number of fossil fuel development and extraction activities, including extraction from public lands, offshore drilling, fracking, mountaintop removal, and imports and exports of fossil fuels. ${ }^{93}$ To protect U.S. manufacturers, he will impose a border adjustment fee on imported fossil fuel-intensive goods, such as steel. To limit the climate impacts of federal legislation, he will introduce a requirement that all federal legislation be scored, or rated, on this basis. ${ }^{94}$

In terms of international cooperation, Sanders plans to have the United States rejoin the Paris Climate Agreement but press for further emissions reductions to limit global warming to $1.5^{\circ}$ Celsius (rather than the $3^{\circ}$ Celsius anticipated by the existing Paris Agreement). ${ }^{95} \mathrm{He}$ would have the United States contribute $\$ 200$ billion to the Climate Green Fund to facilitate emissions reductions in the Global South. ${ }^{96}$

From a historical perspective, one might wonder whether the United States has ever undertaken such an expensive transformational venture as the Green New Deal. Fortunately, there is ample precedent for transformational investments to meet the demands of the era, from the 1930s New Deal

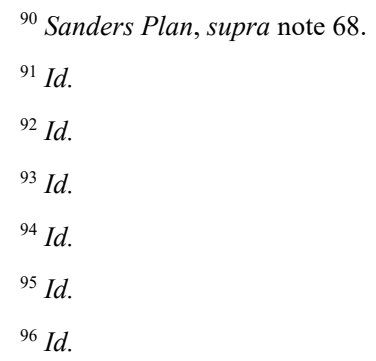

Pitt Tax Review | ISSN 1932-1821 (print) 1932-1996 (online) DOI 10.5195/taxreview.2019.105 | http://taxreview.law.pitt.edu 
programs to counter the Great Depression, to the mobilization of industrial power to prepare for entry into World War II in 1942, to the space race in the 1960 s as a response to the challenges of the Cold War. ${ }^{97}$ The candidates have themselves proposed to repurpose a number of existing programs to meet the challenge of climate change. ${ }^{98}$ From an economic standpoint, one might also question whether all of this direct federal spending is needed and ask why private markets are not undertaking these important projects. The following parts of this Article explain how market failures have spurred government action historically and have fostered demand for the Green New Deal now.

\section{Negative EXTERnAlities: AdDRESSing Climate Change, POLLUTION AND OTHER HARMFUL SPILLOVERS}

Externalities are a form of market failure, one that is very common in environmental contexts. ${ }^{99}$ Actions have costs and benefits and, generally, individuals, business entities, and organizations will pursue a course of action until the moment that their costs exceed their benefits. ${ }^{100}$ When the costs or benefits of an action are shifted to others, economists say these costs or benefits have been externalized. ${ }^{101}$ When an actor does not bear the full cost of his activities and instead shifts a portion of the cost to others, he does not take those shifted costs into account. ${ }^{102}$ He may continue the activity beyond the point that it would be good for everyone affected by the action and,

${ }^{97}$ Several historians, economists and public policy scholars have recounted specific programs that could form models for Green New Deal programs. See, e.g., Louis Hyman, The New Deal Wasn't What You Think, ATLANTIC (Mar. 6, 2019), https://www.theatlantic.com/ideas/archive/2019/03/surprisingtruth-about-roosevelts-new-deal/584209/.

${ }^{98}$ See Sanders Plan, supra note 68 (discussing Sanders's plans to revive the Civilian Conservation Corps for conservation efforts and rely on Power Marketing Administrations and the Tennessee Valley Authority to provide wholesale electricity); see Warren Plan, supra note 38 (discussing how Warren has advocated selling U.S. green energy technologies abroad via a program similar to the post-World War II Marshall Plan). Both Biden and Warren have invoked President John F. Kennedy's Apollo Program to build green energy systems. Biden Plan, supra note 56; Warren Plan, supra note 38.

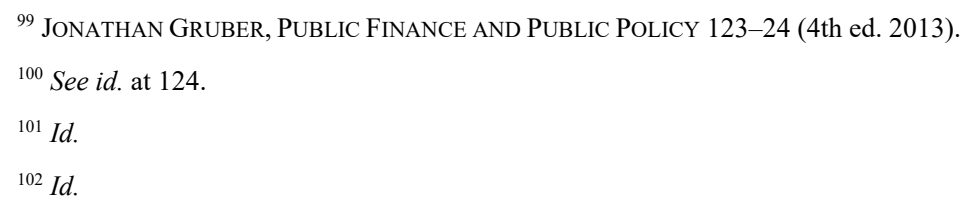

Pitt Tax Review | ISSN 1932-1821 (print) 1932-1996 (online) DOI 10.5195/taxreview.2019.105 | http://taxreview.law.pitt.edu 
ultimately, his actions may cause more harm than good. ${ }^{103}$ Shifted costs are known as negative externalities. ${ }^{104}$

Pollution is a negative externality. ${ }^{105}$ Fossil fuels emit carbon dioxide and other pollutants when they burn. ${ }^{106}$ If the parties burning fossil fuels are not paying a price for the fuel that reflects all of the costs of the fuel's extraction, manufacture, and use (including those borne by the broader society), they are likely to use them to excess. ${ }^{107}$ They will enjoy the benefits of fossil fuels without taking responsibility for the harm they are causing to human health and the environment.

For example, when carbon dioxide and other greenhouse gases are emitted, they aggregate in the atmosphere, trap solar radiation from the sun, and heat the earth's surface. ${ }^{108}$ The resulting global temperature increases are having broad effects on the climate. ${ }^{109}$ While many have experienced the short-term effects of excessive greenhouse gas emissions, the long-term effects may be catastrophic. ${ }^{110}$ Unfortunately, without some form of regulation, fossil fuels will continue to dominate as an energy source, carbon dioxide and other greenhouse gas emissions will continue to build up in the atmosphere, and global warming will accelerate until the earth becomes uninhabitable. ${ }^{111}$

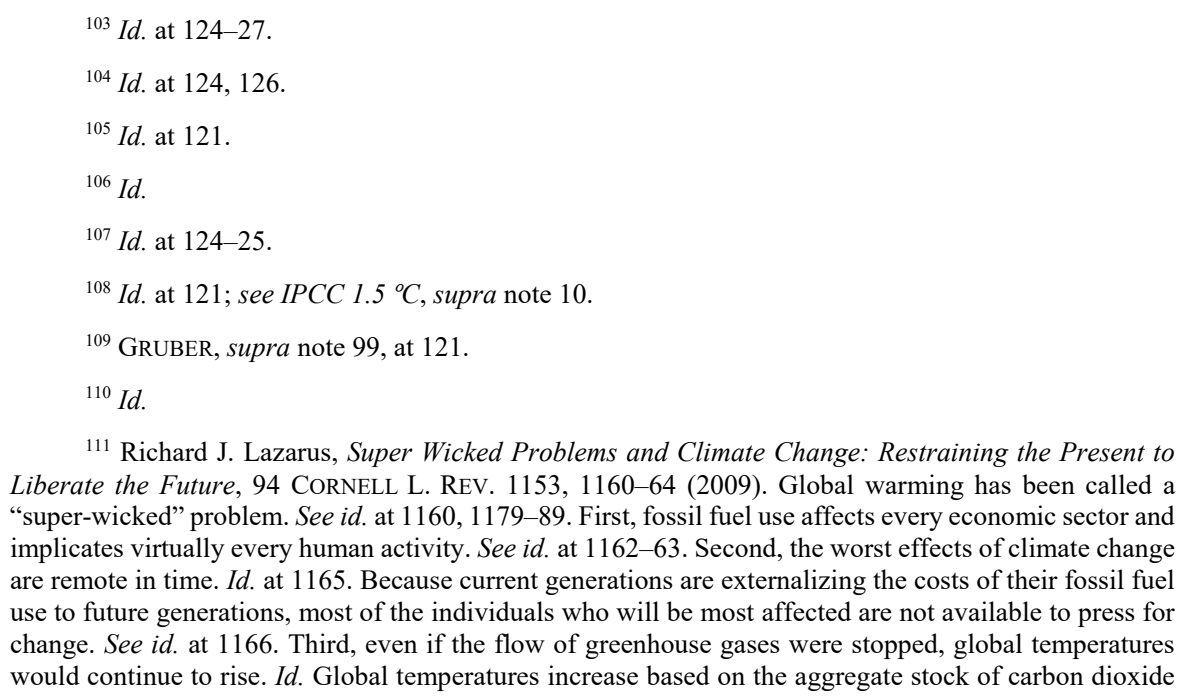

${ }^{111}$ Richard J. Lazarus, Super Wicked Problems and Climate Change: Restraining the Present to Liberate the Future, 94 CORNELL L. REV. 1153, 1160-64 (2009). Global warming has been called a "super-wicked" problem. See id. at 1160, 1179-89. First, fossil fuel use affects every economic sector and implicates virtually every human activity. See id. at 1162-63. Second, the worst effects of climate change are remote in time. $I d$. at 1165 . Because current generations are externalizing the costs of their fossil fuel use to future generations, most of the individuals who will be most affected are not available to press for change. See id. at 1166. Third, even if the flow of greenhouse gases were stopped, global temperatures would continue to rise. $I d$. Global temperatures increase based on the aggregate stock of carbon dioxide

Pitt Tax Review | ISSN 1932-1821 (print) 1932-1996 (online) DOI 10.5195/taxreview.2019.105 | http://taxreview.law.pitt.edu 
Governments may manage market failures in a variety of ways. In general, they focus either on managing quantities or on managing prices. ${ }^{112}$ They may manage quantities by supplying a good in its entirety ${ }^{113}$ or by banning a good or activity altogether. ${ }^{114}$ They may also control quantities by mandating minimum quotas ${ }^{115}$ or by setting maximum caps. ${ }^{116}$ Alternatively, governments may manage market failures through prices. ${ }^{117}$ They may set

in the atmosphere. Id. The current stock of gases has developed over one hundred years. Id. at 1162 . Even if the greenhouse gas levels are stabilized, the stock of greenhouse gases in the atmosphere will remain high and continue to trap heat. Id. at 1164-65. Temperatures will therefore continue to rise long after netzero emissions are attained. Id. at 1165-66. Carbon dioxide reduction, through biological and other means, is needed to reduce that stock. Id. Finally, a number of processes create feedback loops that further reduce the earth's capacity to absorb carbon dioxide. Id. at 1168-72. For example, polar ice and snow reflect solar radiation; declining polar ice and snow heighten solar heat gain. See id. Ocean acidification reduces plankton and other carbon-dioxide absorbing biomass. Id. at 1165.

${ }^{112}$ GrUBer, supra note 99, at 7; see also CLIFFORD WinSTON, AEI-BROOKINGS JOINT CTR. FOR REgUlatory STUDies, GOVERNMENT FAILURE Versus MARKET FAILURE: MicROECONOMICS POLICY RESEARCH AND GOVERNMENT PERFORMANCE 42 (2006).

${ }^{113}$ GRUBER, supra note 99, at 7. For example, many state and local utilities provide public water and sanitary sewer services directly.

${ }^{114}$ Id.; see, e.g., 16 U.S.C. $\S \S 1536(a),(b)(4), 1538(a)-(c)(1)(D)$ (2018) (prohibiting the federal government, private citizens and entities from "taking" a member of an endangered species directly or authorizing another party to do so).

${ }^{115}$ For example, thirty-four countries and ten U.S. states had mandated minimum standards for biofuel blends as of 2016. RENEWABLE ENERGY POL'Y NETWORK FOR THE 21ST CENTURY, RENEWABLES 2016 Global StATUS REPORT 183 (2016). As of the beginning of 2019, twenty-nine states and the District of Columbia had renewable portfolio standards (RPS) specifying the minimum percentage of the electricity that utilities supply to the grid that must be generated from renewable sources, such as solar and wind. Another eight states have voluntary renewable energy targets. State Renewable Portfolio Standards and Goals, NCSL (Dec. 31, 2019), http://www.ncsl.org/research/energy/renewable-portfoliostandards.aspx.

${ }^{116}$ GRUBER, supra note 99 , at 7; WINSTON, supra note 112 , at 42-46. The vast majority of U.S. federal environmental regulations for pollution sets caps. The Clean Water Act, for example, regulates the discharge of pollutants into the nation's surface waters, including lakes, rivers, streams, wetlands, and coastal areas. See 33 U.S.C. $§ 1251$ (a) (2018). It regulates the kinds, amounts, concentrations, and rates at which pollutants are released into U.S. navigable waters and provides national water quality criteria recommendations for states to regulate discharges. Id.

${ }^{117}$ GRUBER, supra note 99, at 7; see WINSTON, supra note 112, at 46-49.

Pitt Tax Review | ISSN 1932-1821 (print) 1932-1996 (online)

DOI 10.5195/taxreview.2019.105 | http://taxreview.law.pitt.edu 
prices, ${ }^{118}$ or they may encourage behavioral changes by imposing taxes, ${ }^{119}$ which increase prices, or by granting subsidies, ${ }^{120}$ which reduce them. ${ }^{121}$ Governments may also create hybrid instruments, such as cap-and-trade programs, ${ }^{122}$ or use a combination of instruments to enhance market efficiency.

Greenhouse gas emissions are negative externalities, harmful spillovers, produced by fossil fuel combustion. ${ }^{123}$ The federal government has considered and implemented several methods to regulate these harmful spillovers, including command-and-control regulation to limit the quantities

${ }^{118}$ Many countries, including Germany and Canada, employ an environmental instrument called the feed-in tariff. Their governments allow utilities to purchase the excess electricity supplied by homeowners and other renewable energy providers connected to the grid at a stipulated minimum price for a fixed period of time. Their goal is to ensure that those investing in renewable energy resources, such as solar and wind, recover the costs of their initial investment over a shorter period of time, reducing their personal risk and diversifying state-wide energy sources. TOBY D. COUTURE ET AL., NAT'L RENEWABLE ENERGy LAB., A POLICYMAKER's GUIDE TO FEED-IN TARIFF POLICY DESIGN 6, 23 (2010).

${ }^{119}$ GRUBER, supra note 99, at 7 . Taxes that are imposed not merely to raise revenues but to change behavior are known as Pigouvian taxes, named for Arthur Pigou, a British economist. HARVEY S. ROSEN \& Ted Gayer, Public FinANCE 82-83 (8th ed. 2008). Pigou clarified that taxes could be used to align private incentives to produce outcomes that were efficient for the broader society. See ARTHUR C. PIGOU, THE ECONOMICS OF WELFARE (4th ed. 1932).

${ }^{120}$ GRUBER, supra note 99, at 7. Subsidies may also be used to encourage certain activities. See WORLD TRADE ORG., WORLD TRADE REPORT 2006: EXPLORING THE LINKS BETWEEN SUBSIDIES, TRADE AND THE WTO 61 (2006).

${ }^{121}$ GRUBER, supra note 99, at 7.

${ }^{122}$ For example, the 1990 amendments to the Clean Air Act required reductions in emissions of sulfur dioxide $\left(\mathrm{SO}_{2}\right)$ and nitrogen oxides $\left(\mathrm{NO}_{\mathrm{x}}\right)$. See Clean Air Act Amendments, Pub. L. No. 101-549, $\S 129$ (a)-(b), 104 Stat. 2399, 2578 (1990). These are pollutants from coal-fired power plants that, when combined with water vapor in the atmosphere, produce acid rain. $I d$. The Acid Rain Program phased-in increasingly stringent caps on the total amount of $\mathrm{SO}_{2}$ and $\mathrm{NO}_{\mathrm{x}}$ emitted and created a permit system to ensure that the total emissions were below those caps. Emitters could then trade their permits. Id. § 401(a)(b), 104 Stat. at 2584-85. Facilities that reduced their emissions below the cap through retrofits or changes in their energy sources could sell their surplus permits to other facilities. Those sales would help cover the costs of the retrofits. Other facilities that might find it more difficult or expensive to retrofit could buy these surplus permits to cover their excess emissions. They could also potentially reduce their production to meet the limit set by their existing emissions permit. However, lower production generally results in reduced revenues.

${ }^{123}$ Sam Zacher, The World's Worst Market Failure: Greenhouse Gas Emissions, GATE (June 1, 2015, 12:19 PM), http://uchicagogate.com/articles/2015/6/1/the-worlds-worst-market-failure-greenhouse -gas-emissions/.

Pitt Tax Review | ISSN 1932-1821 (print) 1932-1996 (online)

DOI 10.5195/taxreview.2019.105 | http://taxreview.law.pitt.edu 
of pollutants spilling into the atmosphere, cap-and-trade policies, taxes on pollution, and mandates and subsidies for nonpolluting alternatives. ${ }^{124}$

\section{A. Command-and-Control Regulation}

To address the threat of climate change, Elizabeth Warren, Joe Biden, and Bernie Sanders have indicated that they plan to reinstate the Clean Power $\mathrm{Plan}^{125}$ or to otherwise regulate greenhouse gas emissions under the Clean Air Act. ${ }^{126}$ The Clean Air Act generally controls air emissions through a command-and-control regime that limits emissions for certain pollutants. ${ }^{127}$

${ }^{124}$ See, e.g., Energy Innovation and Carbon Dividend Act, H.R. 763, 116th Cong. (2019); Climate Action Rebate Act, S. 2284, 116th Cong. (2019); Stemming Warming and Augmenting Pay Act, H.R. 4058, 116th Cong. (2019); Raise Wages, Cut Carbon Act, H.R. 3966, 116th Cong. (2019) (recent carbon tax proposals); American Clean Energy and Security Act, H.R. 2454, 111th Cong. (2009); LiebermanWarner Climate Security Act, S. 2191, 110th Cong. (2007); Low Carbon Economy Act, S. 1766, 110th Cong. (2007); Global Warming Reduction Act, S. 485, 110th Cong. (2007); Climate Stewardship and Innovation Act, S. 280, 110th Cong. (2007) (recent cap-and-trade proposals); Energy Independence and Security Act of 2007, Pub. L. No. 110-140, 121 Stat. 1492 (implementing renewable fuel standards at the federal level); Energy Policy Act of 2005, Pub. L. No. 109-58, 119 Stat. 595 (implementing federal tax credits to support residential solar and commercial solar, geothermal heat pump, and small wind projects); Energy Policy Act of 1992, Pub. L. No. 102-486, 106 Stat. 2776 (providing tax credit for production of electricity from wind, biomass and solar projects); Carbon Pollution Emission Guidelines for Existing Stationary Sources: Electric Utility Generating Units, 79 Fed. Reg. 34,830 (June 18, 2014) (codified at 40 C.F.R. pt. 60) (command and control regime under the Clean Air Act permitting states to develop a variety of alternative approaches).

${ }^{125}$ In 2007, following a lawsuit by Massachusetts and twelve other states, the U.S. Supreme Court issued an opinion directing the EPA to ground its decision not to issue carbon dioxide emissions regulations to address the risks of climate change in the language of the statute. See Massachusetts v. EPA, 549 U.S. 497, 534-35 (2007). In 2015, the Obama Administration finalized regulations under section 111(d) of the Clean Air Act to govern carbon emissions. See Carbon Pollution Emission Guidelines for Existing Stationary Sources: Electric Utility Generating Units, 80 Fed. Reg. 64,661, 64,662-64 (Oct. 23, 2015) (to be codified at 40 C.F.R. pt. 60) [hereinafter Emission Guidelines]. In 2017, the Trump Administration issued an executive order directing the Environmental Protection Agency to review the Clean Power Plan regulations under the Clean Air Act and withdraw appropriate regulations to align with the policy described in the executive order. See Exec. Order No. 13,783, 82 Fed. Reg. 16,093, 16,094-95 (Mar. 31, 2017). On October 10, 2017 the U.S. Environmental Protection Agency repealed the Clean Power Plan. Note that if the Clean Power Plan is reinstated, it will likely be subject to litigation. Repeal of the Clean Power Plan, 84 Fed. Reg. 32,520, 32,522, 32,529 (July 8, 2019) (to be codified at 40 C.F.R. pt. 60). Following the publication of the final Clean Power Plan regulations, a number of lawsuits were filed to contest the regulations. See, e.g., In re Murray Energy Corp., 788 F.3d 330 (D.C. Cir. 2015).

${ }^{126}$ Warren Plan, supra note 38; Biden Plan, supra note 56; Sanders Plan, supra note 68.

12742 U.S.C. $\$ 7401$ (2018). For example, the Clean Air Act authorizes the Environmental Protection Agency to set National Ambient Air Quality Standards (NAAQS) for carbon monoxide, lead,

Pitt Tax Review | ISSN 1932-1821 (print) 1932-1996 (online)

DOI 10.5195/taxreview.2019.105 | http://taxreview.law.pitt.edu 
Under the Clean Power Plan, the EPA established interim and final carbon dioxide emission performance standards for fossil fuel-fired electric steam generating units (generally, coal- and oil-fired power plants), and natural gasfired combined-cycle generating units, and authorized states and tribes to exercise their discretion in determining the best methods for meeting those standards. ${ }^{128}$

In general, Congress has used design standards or performance standards to regulate quantities. ${ }^{129}$ Design standards may require polluters to install certain technologies to trap pollutants or follow certain procedures that will reduce emissions. ${ }^{130}$ Design standards are generally considered to be inefficient. ${ }^{131}$ The costs associated with retrofitting to employ the new technology or new procedures are likely to vary among facilities. ${ }^{132}$ These costs are usually passed forward to consumers in the prices of goods manufactured. ${ }^{133}$ Because costs are likely to be higher for older facilities, these firms may be less competitive than others on price. ${ }^{134}$ Design standards may therefore force some firms out of business; consumers may suffer from higher prices not only resulting from the pass-through of the costs of new technology but because of the decline in supply of the goods the firms produce. ${ }^{135}$ The decrease in supply generates higher profits, sometimes called

ground-level ozone, nitrogen dioxide, particulate matter, and sulfur dioxide. Id. $\S \S 7407(\mathrm{~d})(1)(\mathrm{B})$, 7408(a)-(c), 7409(a)-(c).

${ }^{128}$ See Emission Guidelines, supra note 125, at 64,661-65.

${ }^{129}$ See Robert N. Stavins, Policy Instruments for Climate Change: How Can National Governments Address a Global Problem?, at 299-300 (Res. for the Future, Discussion Paper No. 97-11, 1997).

${ }^{130}$ For example, the Clean Air Act also identifies 187 Hazardous Air Pollutants ("HAPs") and sets health-based limits on their emissions. 42 U.S.C. $\$ 7412$ (b)(1). To implement these limits, the EPA has developed a series of design, or technology-based, emission standards to reduce health risks associated with the HAPs. Id. § 7412(d)(1)-(10).

${ }^{131}$ See Lawrence H. Goulder \& Ian W.H. Parry, Instrument Choice in Environmental Policy 7 (Res. for the Future, Discussion Paper No. RFF DP 08-07, 2008).

${ }^{132} \mathrm{Id}$.

${ }^{133} \mathrm{Id}$. at $7,11$.

${ }^{134}$ See Don Fullerton, A Framework to Compare Environmental Policies, 68 S. ECON. J. 224, 232 33 (2001).

${ }^{135}$ Id. at $238,242$.

Pitt Tax Review | ISSN 1932-1821 (print) 1932-1996 (online) DOI 10.5195/taxreview.2019.105 | http://taxreview.law.pitt.edu 
"windfall profits" or "scarcity rents," for the remaining firms. ${ }^{136}$ Over the long term, design standards may also impede progress. By mandating a particular technology, the government may remove any incentives for firms to innovate and develop new, more cost-effective pollution-abatement technologies. ${ }^{137}$

The Clean Air Act includes performance standards, another form of pollution cap or quantity control. ${ }^{138}$ Governments may set caps for each facility based on past emissions. ${ }^{139}$ Under a performance standard, firms may cut their production to meet the standard, which has similar economic effects to design standards, since supply may decline in the short term, increasing prices to consumers, and generating scarcity rents for the remaining firms. ${ }^{140}$ Like design standards, performance standards also fail to encourage costeffective abatements beyond the cap. ${ }^{141}$ Firms that may abate emissions more cheaply have no incentive to go beyond the limits set forth in their permits. ${ }^{142}$ Therefore, potential societal gains from the cheaper or easier pollution reductions are lost. ${ }^{143}$ In addition, unless regulators increase the stringency of performance standards over time, firms will have little incentive to innovate. ${ }^{144}$

In contrast to design standards and performance standards, marketbased programs, such as environmental taxes and cap-and-trade programs, tend to be more efficient. First, allowing the firm being regulated to decide how to abate its pollution reduces the costs of regulation. ${ }^{145}$ Firms are in the best position to decide how to meet regulatory standards at the least expense

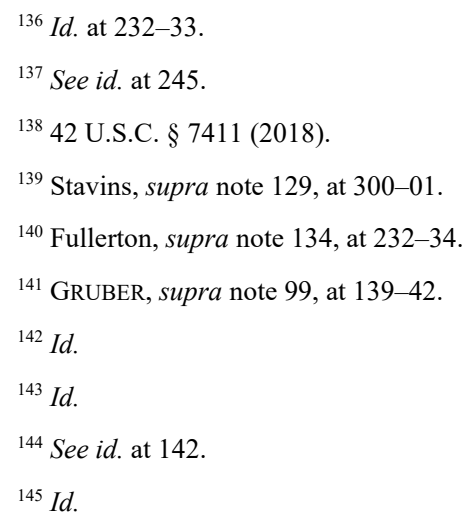

Pitt Tax Review | ISSN 1932-1821 (print) 1932-1996 (online) DOI 10.5195/taxreview.2019.105 | http://taxreview.law.pitt.edu 
because they have the most information. Second, market-based approaches may also generate revenue that governments may use to ease firm transitions and offset some of the costs to consumers.

\section{B. Cap-and-Trade}

The 1990 Clean Air Act Amendments introduced a cap-and-trade system to deal with acid rain. ${ }^{146} \mathrm{Cap}$-and-trade is a market-based approach to regulating emissions. It imposes a quantity control, in the form of a cap, and then allocates emissions permits among the firms that in the aggregate equal the cap. ${ }^{147}$ The firms may then trade their permits. ${ }^{148}$ Thus, the costs and the benefits of emissions abatement are shared among all firms. Cap-and-trade provides several advantages over other quantity-control mechanisms. Because firms may sell their excess permits, they have an economic interest in abating their pollution as much as possible. Because firms may buy permits to cover their emissions, they are less likely to reduce production or to go out of business from failure to meet the emissions caps set forth in their initial permit. Furthermore, if the government auctions the pollution permits, it may use the auction receipts to ease some of the burdens on firms and consumers. $^{149}$

While none of the current presidential candidates are considering a capand-trade regime to control greenhouse gas emissions, cap-and-trade is likely to provide an efficient mechanism for managing greenhouse gas emissions. ${ }^{150}$ Congress has considered a number of cap-and-trade proposals in the last

${ }^{146}$ Title IV of the 1990 Clean Air Act Amendments established the Acid Rain Program. See Clean Air Act Amendments of 1990, Pub. L. No. 101-549, § 401, 104 Stat. 2399, 2584. Part of the Acid Rain Program set a permanent cap for the total amount of sulfur dioxide $\left(\mathrm{SO}_{2}\right)$, one of the precursor chemicals in acid rain, that could be emitted by electric generating units (EGUs) and then brought the cap down over time. EGUs received an initial permit or allowance based on past emissions to cover a portion of their $\mathrm{SO}_{2}$ emissions and then trade their excess allowances in an allowance trading system.

${ }^{147}$ GRUBER, supra note 99, at 142.

${ }^{148} I d$. at $142-43$.

${ }^{149}$ Fullerton, supra note 134, at 233.

${ }^{150}$ See Richard Schmalensee \& Robert N. Stavins, Lessons Learned from Three Decades of Experience with Cap and Trade, 11 REV. ENVTL. ECON. \& POL'Y 59, 62 (2017).

Pitt Tax Review | ISSN 1932-1821 (print) 1932-1996 (online) DOI 10.5195/taxreview.2019.105 | http://taxreview.law.pitt.edu 
decade and a half. ${ }^{151}$ Furthermore, as of 2019, the European Union and twenty other jurisdictions had adopted cap-and-trade systems or cap-andtrade pilot projects to address greenhouse gas emissions. ${ }^{152}$

\section{Pigouvian Taxes}

In contrast to the other candidates, Pete Buttigieg has proposed a taxand-dividend program. ${ }^{153}$ Tax-and-dividend is a market-based mechanism with two components: (1) a Pigouvian tax ${ }^{154}$ on emissions, and (2) a specific allocation of at least a portion of the tax revenue to households impacted by the emissions tax. Economists generally agree that the most efficient way to address climate change is by putting a price on carbon dioxide and other greenhouse gas emissions. ${ }^{155}$ Many consider a carbon or greenhouse gas tax to be the most efficient. ${ }^{156}$

By taxing pollution based on the harm caused per unit, policy makers force polluters to internalize the broader social costs of pollution. ${ }^{157}$ The price

\footnotetext{
${ }^{151}$ See, e.g., American Clean Energy and Security Act, H.R. 2454, 111th Cong. (2009); LiebermanWarner Climate Security Act, S. 2191, 110th Cong. (2007); Low Carbon Economy Act, S. 1766, 110th Cong. (2007); Global Warming Reduction Act, S. 485, 110th Cong. (2007); Climate Stewardship and Innovation Act, S. 280, 110th Cong. (2007).

${ }^{152}$ World BANK Group, State AND TRends of CARbon Pricing 2019, at 14 fig.2 (2019). As of 2019, the European Union and the following countries had implemented cap-and-trade policies or other forms of emissions trading systems: China, Kazakhstan, Korea, New Zealand, and Switzerland. In addition, sixteen subnational groups had implemented cap-and-trade or other emissions trading systems and pilot projects.

${ }^{153}$ Buttigieg Plan, supra note 30.

${ }^{154}$ See generally PIGOU, supra note 119.

155 See J. Scott Holladay et AL., INST. FOR POL'y INTEGRity, ECONOMISTS AND Climate CHANGE: CONSENSUS AND OPEN QUESTIONS, at vii (discussing a survey of 286 economists, which indicated that $97.9 \%$ agreed that a price on carbon would increase incentives for efficiency and innovation, and $91.6 \%$ preferred or strongly preferred "market-based mechanisms, such as a carbon tax or cap-andtrade system" over command-and-control regulation to reduce greenhouse gas emissions).

${ }^{156}$ Alex Brill \& Alex Flint, Comment, Carbon Tax Most Efficient in Tackling Climate Change, Hous. Chron. (Mar. 1, 2019, 5:00 AM), https://www.chron.com/business/energy/article/CommentCarbon-tax-most-efficient-in-tackling-13651878.php; Heather Long, "This is Not Controversial": Bipartisan Group of Economists Calls for Carbon Tax, WASH. POST (Jan. 16, 2019, 7:17 PM), https://www.washingtonpost.com/business/2019/01/17/this-is-not-controversial-bipartisan-groupeconomists-calls-carbon-tax/.

${ }^{157}$ GRUBER, supra note 99, at 135.
}

Pitt Tax Review | ISSN 1932-1821 (print) 1932-1996 (online) DOI 10.5195/taxreview.2019.105 | http://taxreview.law.pitt.edu 
of the good increases with the imposition of the tax. ${ }^{158}$ Demand is lower at the higher price. ${ }^{159}$ Ultimately, production slows to reflect the lower demand, and pollution declines to an equilibrium level at which the total benefit from the availability of the good is equal to the total cost of its production and use, including the effects of pollution. ${ }^{160}$ The goods produced under the carbon tax regime will then reflect the true cost to society of producing or consuming the good. ${ }^{161} \mathrm{~A}$ carbon tax permits policy makers to increase the cost of goods by the increment of damage caused by the carbon dioxide emitted. ${ }^{162}$ Taxes also encourage investment in alternative energy and energy efficiency in both good and bad economies. ${ }^{163}$ The best time to make these investments is during an economic recession, when these modifications would be least expensive. ${ }^{164}$ A cap or a cap-and-trade program may be stymied if production declines during a recession because the caps may be too high to encourage change. ${ }^{165}$ As of 2019 , twenty-two countries had adopted carbon taxes. ${ }^{166}$ The

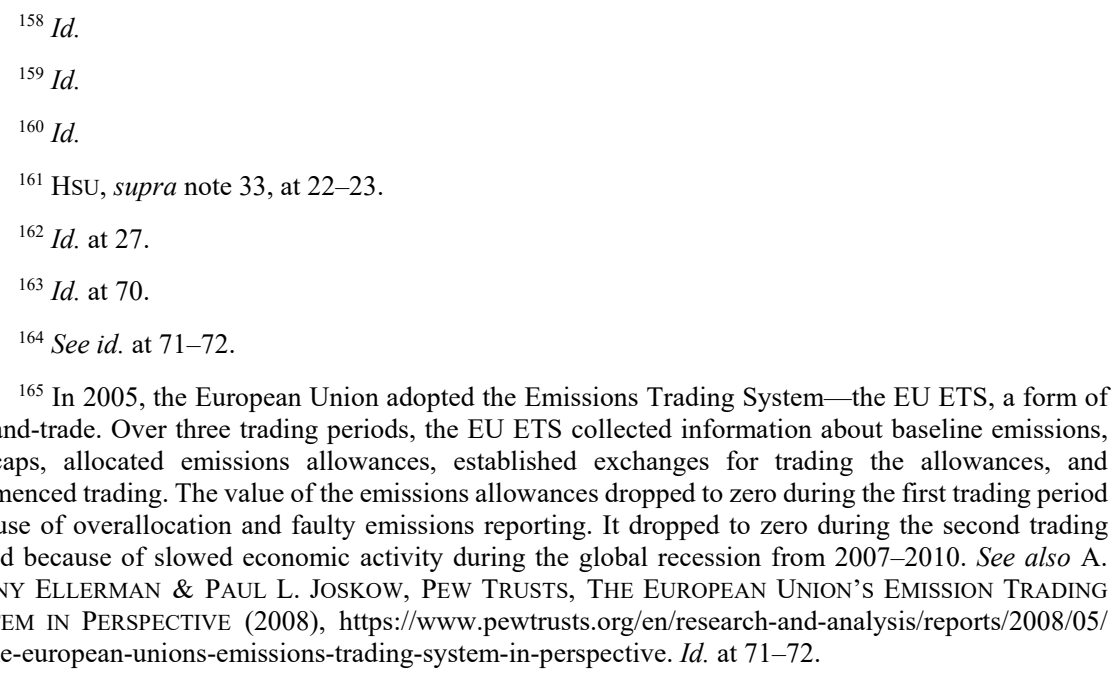

${ }^{166}$ World BANK Group, supra note 152, at 12. By 2017, Chile, Colombia, Denmark, Estonia, Finland, France, Iceland, Ireland, Japan, Latvia, Liechtenstein, Mexico, Norway, Poland, Portugal, Slovenia, South Africa, Sweden, Switzerland, and Ukraine had all implemented carbon taxes.

Pitt Tax Review | ISSN 1932-1821 (print) 1932-1996 (online)

DOI 10.5195/taxreview.2019.105 | http://taxreview.law.pitt.edu 
U.S. Congress has recently begun to consider a number of carbon tax proposals. $^{167}$

Price instruments are more efficient when there is uncertainty about the costs of addressing an externality. ${ }^{168}$ Climate change requires collective action at the global level. Virtually every country contributes to the problem and no unilateral solution will be sufficient to solve it. Immediate action by the United States cannot reduce environmental harms to a substantial degree in the short run because climate change is a "stock-flow" problem. ${ }^{169}$ Temperature changes are the result of the stock of greenhouse gases in the atmosphere; if the United States neutralizes its current greenhouse gas flows into the atmosphere, the temperature will continue to rise until the global stock of greenhouse gases decreases. When there is uncertainty about the social costs of controlling the harm, and the marginal benefits from increasing the stringency of regulation are small, economists prefer regulation of prices to regulation of quantities. ${ }^{170}$ The costs of error from overtaxing to manage climate change have less effect on the economy than errors from setting emissions caps, and the costs of error from undertaxing are not immediately dangerous to the public. ${ }^{171}$ Furthermore, legislators may index the tax rate to emissions reductions, providing for tax rate increases if emissions targets are not met and decreases if the tax is unduly stringent. ${ }^{172}$

The candidates' climate plans also address other forms of pollution. Existing environmental statutes contain a number of taxes that simultaneously function to punish unlawful behavior, to curb certain inherently risky activities, and to generate revenue to cover clean-up costs. For example, Sanders states that he plans to require polluters to clean up hazardous wastes and notes the number of Superfund sites for which recovery

\footnotetext{
${ }^{167}$ See Energy Innovation and Carbon Dividend Act, H.R. 763, 116th Cong. (2019); Climate Action Rebate Act, S. 2284, 116th Cong. (2019); Stemming Warming and Augmenting Pay Act, H.R. 4058, 116th Cong. (2019); Raise Wages, Cut Carbon Act, H.R. 3966, 116th Cong. (2019).

${ }^{168}$ GRUBER, supra note 99, at 143-44.

${ }^{169}$ Lazarus, supra note 111, at 1164-66.

${ }^{170}$ GRUBER, supra note 99, at 144 .

${ }^{171} I d$.

${ }^{172}$ See id. at 104-13.
}

Pitt Tax Review | ISSN 1932-1821 (print) 1932-1996 (online) DOI 10.5195/taxreview.2019.105 | http://taxreview.law.pitt.edu 
has been stalled. ${ }^{173}$ The Comprehensive Environmental Response, Compensation, and Liability Act (CERCLA), also known as the "Superfund" statute, initially imposed an excise tax on petroleum and chemical products to create a fund (the Superfund) to cover cleanup costs for abandoned sites and sites for which the potentially responsible parties charged with cleaning up the site no longer exist or have become bankrupt. ${ }^{174}$ By reinstating the Superfund tax on petroleum and chemical producers, Sanders could expedite the recovery of these sites. Congress has imposed similar excise taxes on a variety of motor fuels ${ }^{175}$ under the Resource Conservation and Recovery Act (RCRA), on ozone-depleting substances ${ }^{176}$ under the Clean Air Act ${ }^{177}$ and on imported and domestic oil under the Oil Pollution Act of $1990 .{ }^{178}$ These taxes could be expanded to redress pollution when existing funds are inadequate.

\section{Subsidies}

Like taxes, subsidies are market-based interventions that may be directed toward either producers or consumers. ${ }^{179}$ Producer subsidies may reduce manufacturing costs or enhance prices for the goods produced. Consumer subsidies may include discounts or rebates on goods. Subsidies may be offered in a variety of forms, such as direct grants or loans, or they may be provided as indirect benefits, such as regulatory concessions, or loan insurance and loan guarantees to reduce risk. Subsidies also take the form of tax preferences. Exclusions, exemptions, deductions from income, special

\footnotetext{
${ }^{173}$ Sanders Plan, supra note 68.

${ }^{174}$ I.R.C. $\S \S 4611,4661$.

175 Certain taxes on gasoline, diesel fuel, kerosene, and other fuels used in commercial transportation and inland waterways are directed to the LUST Trust Fund. See id. §§ 4041, 4042, 4081. Currently, a significant portion of these funds is being diverted to the Highway Trust Fund. See ROBERT S. Kirk \& William J. Mallett, Cong. Research SerV., R45350, Funding and Financing HigHWAYS AND PUBLIC TRANSPORTATION 3 (2019).

${ }^{176}$ Omnibus Budget Reconciliation Act of 1990, Pub. L. No. 101-508, § 11203, 104 Stat. 1388, 1421 (codified at I.R.C. $\$ 4681$ ).

${ }^{177}$ Clean Air Act of 1963, Pub. L. No. 88-206, 77 Stat. 392 (codified at 42 U.S.C. § 7401).

${ }^{178}$ See Oil Pollution Act of 1990, Pub. L. No. 101-380, 104 Stat. 484 (codified at 33 U.S.C. § 2701).

${ }^{179}$ GRUBER, supra note 99, at 135-37.
}

Pitt Tax Review | ISSN 1932-1821 (print) 1932-1996 (online) DOI 10.5195/taxreview.2019.105 | http://taxreview.law.pitt.edu 
rates, deferral of tax liability, and tax credits are all forms of tax subsidies. Tax credits have frequently been used to encourage private equity investments in quasi-public goods with sizeable spillover benefits to the general public, ${ }^{180}$ such as affordable housing ${ }^{181}$ or renewable energy. ${ }^{182}$

When legislatures use subsidies to correct negative externalities, they may take a variety of actions. Specifically, in the context of climate change, the government could potentially pay a manufacturing firm to reduce production, and thereby induce the firm to reduce its greenhouse gas emissions. Or the government could pay the manufacturer to install new, more energy-efficient manufacturing equipment. By providing a subsidy, policy makers reduce the price of energy-enhancing change, making it more affordable. ${ }^{183}$ For example, in the context of climate change, the government could provide a subsidy to encourage a firm to shift to renewable energy and alternative fuels that do not release carbon dioxide or other greenhouse gases. By providing a subsidy, policy makers reduce the price of these substitutes making them more competitive with fossil fuels.

However, if subsidies are the only policies inducing a change to address negative externalities, a partial subsidy may not be sufficient. For example, imagine that the Green New Deal only offers subsidies to encourage firms to acquire pollution-reducing technology. Purchasing the technology will only increase a firm's costs and will not improve its revenues. Therefore, unless the subsidy covers the full cost of purchasing and installing the retrofit, the firm is unlikely to make the change. ${ }^{184}$ If, however, policy makers also begin capping emissions levels or taxing emissions, the firm is more likely to respond. Regulation increases the firm's costs in continuing business-asusual practices. If costs are going to increase over time from using old technology, the economic rationale for shifting to new technology is more readily apparent. If the regulation phases in with increasing stringency, the shift becomes more urgent because delays in making the change will also

\footnotetext{
${ }^{180}$ See infra Part IV.

${ }^{181}$ See, e.g., I.R.C. $\S 42$.

${ }^{182}$ See, e.g., id. $\S \S 45,48$.

${ }^{183}$ See GRUBER, supra note 99, at 136.

${ }^{184}$ William J. Baumol \& Wallace E. OAtes, The Theory of Environmental Policy 214
} (2d ed. 1988).

Pitt Tax Review | ISSN 1932-1821 (print) 1932-1996 (online) DOI 10.5195/taxreview.2019.105 | http://taxreview.law.pitt.edu 
increase firm costs. In addition, if the subsidy is offered only for a finite period, the firm may be spurred to make the change while it can get the subsidized price on the alternative technology.

Furthermore, subsidies, as stand-alone instruments, may also attract new parties to the market that would not operate profitably without the subsidy. ${ }^{185}$ While subsidies may reduce emissions by particular firms, they may encourage less profitable firms to enter the market and increase pollution in the aggregate. ${ }^{186}$ In contrast, a tax on pollution may raise costs just enough to encourage the least profitable firms to close their inefficient operations or to leave the market altogether. ${ }^{187}$ While the remaining firms may increase their production to reach the customers of the firms leaving the market, that increase will be incremental ${ }^{188}$ and, in the aggregate, pollution will decline. ${ }^{189}$ Therefore, subsidies are probably not the optimal instruments to lead the attack on climate change. They may, however, be used in combination with other tools to accelerate a change in producer or consumer behavior.

When designing subsidies, policy makers should consider both the target population and the amount of the subsidy needed to encourage the change in behavior. If the subsidies are too low, people will not take advantage of them and no climate-beneficial shift to less-polluting goods or activities will occur. For example, a recent study of hybrid and electric vehicle subsidies in the United States suggests that the subsidies have been too low to encourage consumers to purchase the vehicles. ${ }^{190}$ While policy makers could wait for the subsidy to become effective when the cost of the new technology declines, a better plan would be to assess the price point at which the targeted consumer would buy the new technologies and set the

\footnotetext{
${ }^{185}$ Id. at 216.

${ }^{186} I d$. at 221.

${ }^{187}$ Id. at 216.

${ }^{188} \mathrm{Id}$. at 220.

${ }^{189} I d$. at 221 (remaining firms will pay a higher level of income tax producing revenues that may be recycled to further reduce emissions).

${ }^{190}$ Cong. Budget Office, EfFEcts of Federal TAX Credits For the Purchase of EleCtric VEHICLES 6-9 (2012). The United States seeks to reduce ambient pollutants and carbon dioxide emissions produced by vehicles with traditional combustion engines by providing subsidies to encourage the substitution of electric vehicles.
}

Pitt Tax Review | ISSN 1932-1821 (print) 1932-1996 (online) DOI 10.5195/taxreview.2019.105 | http://taxreview.law.pitt.edu 
subsidy at the level needed to encourage the purchase. On the other hand, if the firm or individuals taking advantage of a subsidy would have taken the action or purchased the good anyway, then the subsidy has been wasted; it has not induced any change in behavior. Therefore, policy makers should identify the firms and households that would otherwise not make the shift and tailor the subsidy to that group.

Note that many existing federal subsidies have unintended climaterelated side effects. For example, federal tax subsidies for housing have encouraged the development of energy wasting megamansions and increased sprawl. ${ }^{191}$ These subsidies should, therefore, be modified or reconsidered as part of the Green New Deal.

\section{E. Mandates and Bans}

Regulatory mandates require that consumers purchase, or that producers supply, a certain level of goods. For example, the United States has mandated renewable fuel standards to reduce pollution. ${ }^{192}$ As with subsidies, mandates may be less efficient than other forms of regulation because policy makers must identify the substitute good they are going to mandate rather than allowing markets to identify the best substitutes. In addition, firms will find it more expensive to comply if a mandate is imposed when supply of the mandated good is low. If production costs are too high, producers may simply produce less, creating scarcity. Likewise, if the mandated good is too expensive, consumers may purchase fewer mandated goods, buy alternative goods, or go without. Each of these options reduce welfare. If the reduction in welfare from the mandate exceeds the benefits that society receives from improvements to the environment, there is a net loss to society.

Bernie Sanders has included a number of mandates in his climate plan. For example, he plans to impose a federal mandate through the Department

\footnotetext{
${ }^{191}$ See Roberta F. Mann, The (Not So) Little House on the Prairie: The Hidden Costs of the Home Mortgage Interest Deduction, 32 ARIZ. ST. L.J. 1347 (2000).

${ }^{192}$ See, e.g., Energy Independence and Security Act of 2007, Pub. L. No. 110-140, 121 Stat. 1492 (implementing renewable fuel standards at the federal level); Energy Policy Act of 2005, Pub. L. No. 10958, 119 Stat. 594 (implementing renewable fuel standards at the federal level). As of 2016, ten U.S. states had mandates that required that transportation fuel sold within their jurisdictions contain a minimum percentage by volume of renewable fuels, such as ethanol or biodiesel. RENEWABLE ENERGY POL'Y NETWORK FOR THE 21ST CENTURY, supra note 115, at 183.
}

Pitt Tax Review | ISSN 1932-1821 (print) 1932-1996 (online) DOI 10.5195/taxreview.2019.105 | http://taxreview.law.pitt.edu 
of Energy to require wealthier homeowners and building owners to meet the energy retrofit requirements. ${ }^{193}$ A better policy in the housing context might be to eliminate tax subsidies in support of real estate ownership, such as the home mortgage interest deduction, ${ }^{194}$ the exclusion of gains on sale of a primary residence, ${ }^{195}$ and the availability of like-kind exchanges on commercial real estate, including multifamily residential rental units, ${ }^{196}$ limiting the availability of those subsidies to buildings meeting certain weatherization or green building standards. ${ }^{197}$ This, of course, will add complexity to the income tax and will be difficult to document and enforce, but probably no more so than the energy-efficiency and weatherization deductions and credits previously available in the income tax. ${ }^{198}$ Note that while the U.S. Supreme Court has found federal mandates to be problematic from a constitutional perspective, ${ }^{199}$ it has held that tax subsidies and their limitation and removal are a matter of legislative grace. ${ }^{200}$

The federal government may also ban certain activities. For example, the Endangered Species Act prohibits the federal government from taking an action that would result in the "taking" of a member of an endangered species directly or authorizing another party to do so. ${ }^{201}$ It also bars private citizens and entities from taking endangered species, making it unlawful for any

${ }^{193}$ Sanders Plan, supra note 68 . Sanders has plans to subsidize small businesses and low- and moderate-income families to retrofit and weatherize their buildings and homes.

${ }^{194}$ I.R.C. $§ 163(\mathrm{~h})(2)(\mathrm{d}),(3)$.

${ }^{195}$ See id. $\S 121$.

${ }^{196}$ Id. $\S 1031$.

197 See, e.g., LEED Green Building Certification, U.S. GREen BLDG. Council, https://new.usgbc.org/leed (last visited Dec. 28, 2019); see also Living Building Challenge Certification, INT'L LIVING FUTURE INST., https://living-future.org/lbc/certification/ (last visited Dec. 28, 2019).

${ }^{198}$ See I.R.C. $\S$ 25C, 45L, 179D (all expired Dec. 31, 2017).

${ }^{199}$ See Nat'l Fed'n of Indep. Bus. v. Sebelius, 567 U.S. 519 (2012) (holding that an individual mandate requiring U.S. residents to buy health insurance was invalid as an exercise of congressional power under the Commerce Clause but authorized under the taxing power).

${ }^{200}$ New Colonial Ice Co. v. Helvering, 292 U.S. 435, 440 (1934) (“Whether and to what extent deductions shall be allowed depends upon legislative grace; and only as there is clear provision therefor can any particular deduction be allowed.”); White v. United States, 305 U.S. 281, 292 (1938).

${ }^{201}$ See 16 U.S.C. $\S 1536$ (2018).

Pitt Tax Review | ISSN 1932-1821 (print) 1932-1996 (online) DOI 10.5195/taxreview.2019.105 | http://taxreview.law.pitt.edu 
person to import, export, possess, sell, deliver, receive, carry, transport ship, sell, or offer for sale the species in interstate or foreign commerce. ${ }^{202}$

Both Sanders and Warren plan to terminate or ban a number of fossilfuel related operations, including ending fossil fuel extraction activities on federal lands; ending permits for fossil fuel extraction, transportation, and refining infrastructure; banning fracking and mountaintop removal coal mining; and banning imports and exports of fossil fuels. ${ }^{203}$ Bans may raise other constitutional issues under the Fifth Amendment Takings Clause. ${ }^{204}$ Under the current takings doctrine, a regulatory action will necessitate the payment of compensation as a per se matter if the government or its designees physically occupy the property ${ }^{205}$ or the regulation leaves the owner with no economically viable use for the property. ${ }^{206}$ Otherwise, the courts apply a multifactor test in which the court weighs (1) the extent of the economic impact of the regulation on the property, (2) the extent to which the regulation interferes with investment-backed expectations, and (3) the character of the government action. ${ }^{207}$ While changes in future policy are warranted, bans or stringent regulation of currently unregulated uses are likely to face litigation.

\section{F. Managing Unintended Effects of All Climate Change Instruments}

Each of the above-described climate change regulatory options will have two sets of impacts that will need to be managed. First, regardless of which form of regulatory control Congress may choose, there will be broad economic impacts that will affect every household in the United States. Second, there will be harmful competitive effects on U.S. businesses relative

${ }^{202} I d$. $§ 1538$ (a).

${ }^{203}$ See Sanders Plan, supra note 68; see also Warren Plan, supra note 38.

${ }^{204}$ The Takings Clause of the U.S. Constitution provides "nor shall private property be taken for public use, without just compensation." U.S. CONST. amend. V.

${ }^{205}$ Loretto v. Teleprompter Manhattan CATV Corp., 458 U.S. 419, 434-35 (1982).

${ }^{206}$ Lucas v. S.C. Coastal Council, 505 U.S. 1003, 1052 (1992). An exception exists to per se regulatory takings when "background principles of nuisance and property law" independently restrict the owner's use of the property. Id.

${ }^{207}$ Penn Cent. Transp. Co. v. New York City, 438 U.S. 104, 124 (1978).

Pitt Tax Review | ISSN 1932-1821 (print) 1932-1996 (online) DOI 10.5195/taxreview.2019.105 | http://taxreview.law.pitt.edu 
to businesses operating in jurisdictions that do not regulate greenhouse gases. Each of these effects can be managed.

\section{Distributional Impacts}

Regulatory caps, cap-and-trade programs, and carbon taxes all raise concerns about the distributional impacts on consumers. ${ }^{208}$ Many economists predict that the majority of the costs of climate regulation will be passed forward to consumers. ${ }^{209}$ Subsidies, on the other hand, are thought to be inefficient and will impact households because other taxes must be raised to cover the costs of the subsidies. ${ }^{210}$ Both greenhouse gas taxes and the auctioning of allowances in a cap-and-trade program allow the government to capture the lost consumer and producer surplus as revenue. ${ }^{211}$ The government may then use that revenue to offset the distributional impacts of the climate regulatory regime. ${ }^{212}$ Many economists propose to use revenues from a greenhouse gas tax to offset other taxes, reducing distortions in the tax system. ${ }^{213}$ However, some of these efforts may undercut the effects of a greenhouse gas tax and others are less equitable because they do not reach all households that will be affected by the tax. ${ }^{214}$ Managing the distributional impacts may be done most efficiently through a lump-sum rebate. ${ }^{215}$

${ }^{208}$ Some have suggested that the Green New Deal's proponents have been avoiding discussions of carbon taxes because of the likely financial impacts on low- and moderate-income households. However, these impacts will be felt regardless of whether legislators reinstate the Clean Power Plan or employ carbon taxes or other measures to address climate change.

${ }^{209}$ See Terry Dinan, Taxing Carbon Dioxide Emissions: Key Issues, in TAX LAW AND THE ENVIRONMENT: A MUlTIDISCIPLINARY AND WORLDWIDE PERSPECTIVE 199, 203-13 (Roberta F. Mann \& Tracey M. Roberts eds., 2018).

${ }^{210}$ While the federal income tax is somewhat progressive, other taxes are less so or are regressive. Some taxes cause additional efficiency losses by deterring work and investment.

${ }^{211}$ Roberts, supra note 35, at 225, 227.

${ }^{212} I d$. at 240

${ }^{213}$ Joseph Rosenberg ET AL., TAX POLICY CTR., Distributional IMPLiCATIONS OF A CARBON TAX 21-22 (2018); Roberton C. Williams III et al., The Initial Incidence of a Carbon Tax Across Income Groups (Res. for the Future, Discussion Paper No. RFF DP 14-24, 2014) ("Although carbon taxes are regressive, how the revenue is used - to cut capital taxes, given as a lump sum rebate, or for a labor tax swap-impacts how much the poorest populations are affected."); see Dinan, supra note 209, at 211-13.

${ }^{214}$ RosenBERG ET AL., supra note 213, at 23 tbl.4a; Williams et al., supra note 213, at 15 fig.2.

${ }^{215}$ See Roberts, supra note 35, at 240-42.

Pitt Tax Review | ISSN 1932-1821 (print) 1932-1996 (online) DOI 10.5195/taxreview.2019.105 | http://taxreview.law.pitt.edu 
A tax-and-dividend regime will return some or all of the revenues from the carbon tax to consumers. While Buttigieg has no details about his plan, it appears to be similar to a proposal promoted by the Climate Leadership Council $^{216}$ and endorsed by economists and politicians from across the political spectrum. ${ }^{217}$ That plan proposes to begin with a tax of $\$ 40$ per ton on carbon dioxide emissions and to use all of the revenues generated to provide a uniform $\$ 2,000$ dividend to all households. ${ }^{218}$ This dividend would likely completely offset the financial impacts to lower-income households, but cover only a portion of costs to the middle and upper classes. ${ }^{219}$ If the government were to raise the tax and hold the dividend constant, however, it could deploy the surplus revenues to effectuate other parts of the Green New Deal. $^{220}$

\section{Trade Impacts}

Climate regulation (of any kind) is also likely to affect competition in domestic and foreign trade. The United States may act unilaterally to regulate greenhouse gases, but by increasing the cost of greenhouse gas emissions, it may put its manufacturing sector at a disadvantage relative to manufacturers in jurisdictions that have not addressed climate change. Goods produced in a jurisdiction with greenhouse gas regulation will be more expensive than goods produced in countries without such regulation. Domestically produced goods will face a price disadvantage in global markets unless there is an adjustment at the border to neutralize the financial impacts of greenhouse gas regulation on the price of the good. Likewise, imported foreign goods from jurisdictions without carbon regulation are likely to be less expensive than domestically produced goods, unless the foreign imports are subject to a

\footnotetext{
${ }^{216}$ See Climate LeAdership CounCIL, supra note 34.

${ }^{217}$ See Economists' Statement on Carbon Dividends, WALL ST. J. (Jan. 16, 2019, 6:55 PM), https://www.wsj.com/articles/economists-statement-on-carbon-dividends-11547682910.

${ }^{218}$ Climate LeAdership COUNCIL, supra note 34.

${ }^{219}$ Roberts, supra note 35, at 241.

${ }^{220}$ Some countries have recycled the revenues received from greenhouse gas and fuel taxes to accelerate the transition to clean energy. For example, the carbon pricing schemes in Alberta and Quebec, Canada, the Regional Greenhouse Gas Initiative, and the California cap-and-trade program all provide for carbon pricing revenues to support the installation of renewable energy technologies and building retrofits for improved energy efficiency. See InT'L COUnCIL on Mining \& Metals, Options in RECYCLING Revenue Generated Through CARBon Pricing 39 app. B (2013).
}

Pitt Tax Review | ISSN 1932-1821 (print) 1932-1996 (online) DOI 10.5195/taxreview.2019.105 | http://taxreview.law.pitt.edu 
border adjustment that mimics the price effects of the domestic greenhouse gas regulation. To avoid these impacts, firms may move to jurisdictions where greenhouse gases are not regulated, a response known as carbon leakage. The Sanders plan to impose border adjustments is therefore an apt mechanism to deter carbon leakage. ${ }^{221}$

\section{PUBLIC GOODS AND POSITIVE EXTERNALITIES: SUPPORT FOR INFRASTRUCTURE AND THE ENVIRONMENT}

Historically, the United States and other countries have invested enormous sums to build energy, water, communications, and transportation infrastructure. ${ }^{222}$ Given the size of the U.S. economy and the depth of its capital markets, one might wonder why private markets are not supplying these goods. ${ }^{223}$ As a matter of principle, economists generally hold that markets are the best and most efficient mechanism for allocating goods and services in society. ${ }^{224}$ Private parties, all with sufficient market access, knowledge, and the ability to trade, will exchange goods and services until the combination of prices and quantities meet the parties' needs and no further trades would improve one person's welfare without reducing that of another. $^{225}$ Markets do not always function perfectly, however. ${ }^{226}$

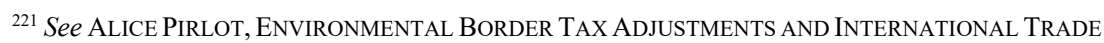
LAW: Fostering EnVIRONMENTAL PROTECTION 80 (2017). Border adjustments are designed to neutralize the harmful effects of domestic taxes on competition. $I d$. at 47 . By imposing a tax on imported foreign goods equal to the effects of the carbon price on domestic goods, the border adjustment will eliminate the price advantage that foreign firms would otherwise enjoy in domestic trade. Id. By providing a rebate to reduce the carbon price on domestic goods entering international trade, border adjustments again eliminate competitive effects of the carbon pricing scheme. Id.

${ }^{222}$ For example, in the early 1800 s, the United States financed the construction of the Erie Canal to enhance commercial trade, and the Natchez Trace to extend from Nashville to the Mississippi River, to improve road access over a portion of the land acquired through Louisiana Purchase. In the mid-nineteenth century, the federal government granted private railroad companies public lands and forced the sale of private rights-of-way to build the transcontinental railway. In the twentieth century, it financed the development of the interstate highway system to enhance private and commercial transportation options.

${ }^{223}$ Edward D. Kleinbard, We Are BetTer Than This: How Government Should SPend OUR MONEY 275 (2015).

${ }^{224}$ GRUBER, supra note 99 , at 3.

${ }^{225} \mathrm{Id}$.

${ }^{226} I d$. at 4 .
}

Pitt Tax Review | ISSN 1932-1821 (print) 1932-1996 (online) DOI 10.5195/taxreview.2019.105 | http://taxreview.law.pitt.edu 
Information asymmetries, ${ }^{227}$ barriers that keep parties from entering the market, ${ }^{228}$ exercises of market power through monopoly (in which suppliers control prices), ${ }^{229}$ or monopsony (in which purchasers control prices) ${ }^{230}$ are all forms of market failure. ${ }^{231}$ When market failures occur, government intervention to eliminate barriers to access, improve competition, and correct information asymmetries and other impediments can enhance efficiency. ${ }^{232}$

\section{A. Economic History: Public Goods, Natural Monopolies, and Positive Externalities}

One common form of market failure involves the concept of "public goods." Public goods are distinguished from private goods (the majority of goods people encounter) in that they are nonrival and nonexcludable. ${ }^{233} \mathrm{~A}$ vehicle is a private good. Two people cannot drive it at the same time, therefore the good is characterized conceptually as a rival good. One person can exclude another from using the car, so the good is therefore "excludable." In contrast, public goods may be enjoyed by many people at the same time, so they are nonrival. ${ }^{234}$ Because one person cannot easily block another from enjoying the good, they are also nonexcludable. ${ }^{235}$

Ideas are examples of public goods. If one person develops a good idea and shares it, others may use the idea without reducing the value of the idea; ideas are therefore nonrival. Once the idea is shared or otherwise communicated, however, it is not possible to keep others from using it; ideas are also therefore nonexcludable. Those who obtained the idea from another

${ }^{227}$ Id. at $328-33$.

${ }^{228}$ N. GRegory MANKIW, PRinCiPles of Microeconomics 331 (6th ed. 2012).

${ }^{229} I d$. at 11.

${ }^{230} \mathrm{Id}$. at 389

${ }^{231} \mathrm{Id}$. at $11-12$.

${ }^{232}$ GRUBER, supra note 99, at 5.

${ }^{233} \mathrm{Id}$. at 184. Public goods are nonrival and nonexcludable; consumption of the good does not keep others from consuming it, and one does not have the physical capacity to exclude others. Id.

${ }^{234} \mathrm{Id}$.

${ }^{235} \mathrm{Id}$.

Pitt Tax Review | ISSN 1932-1821 (print) 1932-1996 (online) DOI 10.5195/taxreview.2019.105 | http://taxreview.law.pitt.edu 
may "free-ride" on that person's efforts in originating the idea; that is, they may enjoy the idea without acknowledging or paying the person who developed the idea in the first place. ${ }^{236}$ If the individual who developed the idea cannot benefit financially from sharing the idea, he may choose not to share the idea at all. Consequently, even though the idea may have a broad benefit to society, it may not reach everyone who could put it to beneficial use.

Private firms will only supply goods to the extent that they can capture monetary benefits from the use of the good; they do not count the benefits to free-riders when they determine their level of investment. ${ }^{237}$ Public goods therefore tend to be undersupplied. ${ }^{238}$ Many private goods also provide some level of generalized public benefit. ${ }^{239}$ These are known as "impure public goods" or "quasi-public goods." ${ }^{40}$ Governments may enhance efficiency by intervening in the market to support the production of public and quasi-public goods and expand the number of people who may benefit from them. ${ }^{241}$

Clean water and sanitary sewer systems, reliable electricity, transportation, and telecommunications systems are all quasi-public goods. ${ }^{242}$ The public health value, productivity gains, network effects, and other indirect benefits of these resources extend far beyond the private

\section{${ }^{236} I d$. at 183.}

${ }^{237}$ KLEINBARD, supra note 223, at 277 (“'II]f private entrepreneurs do not capture all of the returns from a class of investment, the total private pool of such investments will fall short of the optimal level from the perspective of society as a whole.").

${ }^{238}$ GRUBER, supra note 99, at 128-29 (explaining that private markets will decline to invest at the appropriate level in public goods because they cannot appropriate all of the benefits from the activity).

${ }^{239}$ Education is a good example of a quasi-public good. While a student may receive much of the benefit of his or her education, the broader society benefits from having an educated citizenry and workforce.

${ }^{240}$ GRUBER, supra note 99, at 184.

${ }^{241} I d$. at $187-89$. For example, the U.S. government grants intellectual property rights through patent and copyright laws to individuals who turn their ideas into sufficiently concrete form. These laws grant the individual a monopoly, the exclusive right to license the use of their idea (in its concrete form) for a period of years. Intellectual property laws provide a monetary incentive that encourages inventors and authors to make their inventions and innovations more broadly available.

\footnotetext{
${ }^{242}$ KLEINBARD, supra note 223, at 276-77.
}

Pitt Tax Review | ISSN 1932-1821 (print) 1932-1996 (online) DOI 10.5195/taxreview.2019.105 | http://taxreview.law.pitt.edu 
benefits enjoyed by the household with access to them. ${ }^{243}$ Furthermore, investments in infrastructure create well-paying construction jobs, which in turn enhance family income and overall public welfare. ${ }^{244}$

Historically, other dynamics have inhibited private markets in fully occupying the utilities and transportation sectors. ${ }^{245}$ Most utilities have faced enormous initial construction costs. ${ }^{246}$ Once constructed, however, the costs of extending access to additional customers has been nominal. ${ }^{247}$ Consequently, the first party to develop and supply the service could undercut later competitors on price. ${ }^{248}$ Duplication of the production facilities was wasteful and sometimes resulted in bankrupted utilities and loss of

${ }^{243} I d$. at 277. For example, new public transportation options reduce vehicular traffic and congestion. Id. A private bus line may not take into consideration these benefits, but a government will.

${ }^{244} I d$. at 278. Infrastructure investment yields a triple return. Id. at 284. It improves private productivity on average in the range of eight to ten percent. Id. at 283 . There are many gains that are not captured by productivity measures including cleaner air and a faster commute. $I d$. at 284 . Infrastructure projects provide meaningful dignified work that pays good wages. Id. Finally, those wages are used to acquire healthcare and education, which have broad public benefits, as well as goods and services from every sector of the economy. Id. at 278. Finally, infrastructure projects initiated during recessions and can be initiated at times when there is no technological breakthrough that would otherwise spur private investment, balancing private investment trends and reducing the turbulence of investment cycles. $I d$. at 285 .

${ }^{245}$ Charles F. Phillips, JR., The Regulation of Public Utilities 4 (2d ed. 1988) ("Public utilities ... tend toward monopoly or, more accurately, the firms in these industries seem to operate more efficiently as monopolies. Yet, if economic power is not to be controlled by the market, it must be controlled by public authority, for a firm's contribution to the general welfare, rather than being the result of voluntary choice, must be compelled. Some regulation, moreover, may be undertaken for social or political reasons, such as promoting regional development or for national defense purposes.").

${ }^{246}$ Joseph P. Tomain, Ending DirTy Energy Policy: Prelude to Climate Change 44 (2011). Note that today distributed energy from solar panels makes low-cost local energy possible. However, access to the electrical grid (which was constructed at extraordinary cost) allows homeowners installing solar panels to share their excess renewable electricity with others. Net-metering regulations allow solar owners to recover their investment costs more quickly. By netting the value of their electricity production against their electricity costs when they draw from the grid (usually during peak hours or at other times when solar production is not sufficient), their energy savings are increased.

247 See Amy Abel, Cong. Research Serv., 98-419 ENR, Electricity Restructuring BaCKground: THe Public Utility Regulatory Policies ACt OF 1978 AND THE ENERGy Policy ACt OF 1992, at 2 (1998).

${ }^{248}$ Peter Z. Grossman, Is Anything a Natural Monopoly, in The END of A NATURAL MonOpoly: DeRegulation AND COMPETiTion In the Electric Power Industry 10, 12 (Daniel H. Cole \& Peter Grossman eds., 2014).

Pitt Tax Review | ISSN 1932-1821 (print) 1932-1996 (online)

DOI 10.5195/taxreview.2019.105 | http://taxreview.law.pitt.edu 
service. ${ }^{249}$ Duplication of the distribution lines did not improve service; instead, they multiplied maintenance costs, land use challenges, and public hazards. ${ }^{250}$ Because of these characteristics, early regulators classified utilities as "natural monopolies." "251 Governments enjoy lower costs of financing because they may use tax revenues to build facilities or issue bonds backed by their taxing authority, and may pass forward to consumers the bare costs of construction. ${ }^{252}$ Private firms, on the other hand, must earn a financial return on their investment. ${ }^{253}$ Government timelines for recouping construction costs are also far longer than for private investors, who may be deterred by long investment horizons. ${ }^{254}$ However, rather than constructing all energy generation and distribution systems themselves, governments have developed a hybrid model, the regulated public utility. ${ }^{255}$ Governments encourage private capital investment by granting a monopoly, shielding the utility from competition, and then regulating prices and services to protect the interests of consumers. ${ }^{256}$ For much of the energy and transportation sectors, governments continue either to provide these services directly, or they operate as regulated monopolies.

Positive externalities are also market failures. They occur when the benefits of a party's actions spill over to others. As with public goods, if an actor does not reap all of the benefits associated with his actions, he may discontinue the activities sooner than would be optimal for society. Consequently, those benefits will be undersupplied. Agricultural land,

\footnotetext{
${ }^{249}$ LinCOLN DAVIES ET AL., ENERgy LAW AND POLICY 284-85, 289 (2d ed. 2018).

${ }^{250} \mathrm{Id}$.

${ }^{251} I d$. at 284 .

${ }^{252}$ KLEINBARD, supra note 223, at 276.

${ }^{253} I d$.

${ }^{254} \mathrm{Id}$. To compare the profitability of two projects, investors examine the projects' income streams, with the annual income discounted to present value. Investors will prefer projects that support a higher return over a shorter period of time. ROSEN \& GAYER, supra note 119, at 153-55. As a result of the huge costs associated with developing projects with very high initial capital costs and the long periods over which those costs may be recovered, private firms will tend not to invest in these projects, particularly if other investments are more profitable. Id.
}

${ }^{255}$ DAVIES ET AL., supra note 249, at 284.
${ }^{256}$ Id.

Pitt Tax Review | ISSN 1932-1821 (print) 1932-1996 (online) DOI 10.5195/taxreview.2019.105 | http://taxreview.law.pitt.edu 
grasslands, and forests supply significant ecosystem services through carbon sequestration. ${ }^{257}$ Because these benefits go largely unrecognized and the world fails to pay for the benefits they receive, these forest stocks and other natural resources are undervalued. Currently, farmers are clearing Indonesian forests to plant palm trees for the production of palm oil. Likewise, ranchers and farmers are clearing the Amazon rainforest for cattle ranching and soybean production. Markets currently recognize the monetary value of palm oil, soybeans, and beef; they do not recognize the value of rainforest as a carbon sink, based on its capacity to absorb carbon dioxide, or the cultural and environmental significance of its biodiversity. One possible response to the problem of public goods is to recognize, in monetary terms, the inherent value of these forests and the ecosystem services they are providing globally. ${ }^{258}$

Private markets fail to supply public goods and quasi-public goods and fail to account for positive externalities. Government subsidies and other supports can increase their supply and improve economic outcomes and climate resilience in the United States.

${ }^{257}$ Carbon sequestration is the process whereby carbon dioxide is removed from the atmosphere and fixed. What Is Carbon Sequestration?, U.S. GEOLOGICAL SURVEY, https://www.usgs.gov/faqs/whatcarbon-sequestration (last visited Jan. 19, 2020). It may be stored through a biological process as a form of organic material such as soil, vegetation, and aquatic systems. What's the Difference Between Geologic and Biologic Carbon Sequestration?, U.S. GeOLOGICAL SuRVEY, https://www.usgs.gov/faqs/what-sdifference-between-geologic-and-biologic-carbon-sequestration? (last visited Jan. 19, 2020). Carbon sequestration may also be achieved through artificial processes that involve carbon dioxide removal from the atmosphere, conversion into a liquid, and long-term storage through geoengineering processes. Id.

${ }^{258}$ At the international scale, countries have considered making payments to developing countries where the key forests are located in an effort to reduce emissions from deforestation and forest degradation. The United Nations Framework Convention on Climate Change (UNFCCC) is an international environmental treaty, drafted in 1992 at the Earth Summit in Rio de Janeiro. The treaty established a framework for investigating, mitigating, and managing the effects of climate change; it has been ratified by 196 nations, including the United States, as well as the European Union. Every few years the United Nations institutes a Conference of the Parties to the UNFCCC to discuss the most recent science and collaborative actions to address climate change. At COP-13, the parties agreed that reducing emissions from deforestation and degradation (REDD) should be part of the comprehensive effort to address climate change. In 2010, at COP-16, REDD was expanded to include conservation, sustainable management practices and forest expansion. See Reducing Emissions from Deforestation and Forest Degradation and the Role of Conservation, Sustainable Management of Forests and Enhancement of Forest Carbon Stocks in Developing Countries (REDD-plus), U.N. CLIMATE CHANGE, https://unfccc.int/ topics/land-use/workstreams/reddplus (last visited Dec. 28, 2019).

Pitt Tax Review | ISSN 1932-1821 (print) 1932-1996 (online)

DOI 10.5195/taxreview.2019.105 | http://taxreview.law.pitt.edu 


\section{B. Energy and Transportation Infrastructure}

This section describes the various ways the U.S. government has addressed the above-described market failures. It also examines and critiques the various instruments employed to manage these problems and provides guidance on the use of tax instruments to effectuate the candidates' infrastructure proposals.

The bulk of the candidates' plans focus not on greenhouse gas regulation, but on federal investments designed to transform the economy. While governments may provide public goods and quasi-public goods in their entirety, full government provision may crowd out private supply. ${ }^{259}$ If the government takes full charge of all expenditures for development of a public or quasi-public good, such as infrastructure, the result may be little net gain in the availability of the good. ${ }^{260}$ Governments find it difficult to measure public preferences for public goods and to determine their optimal level. ${ }^{261}$ Therefore, most governments provide subsidies to encourage their development. By delivering a subsidy, the government avoids crowd-out but reduces the risks that deter private investors and state and local policy makers from committing funds to develop these goods.

Unfortunately, a number of hazards accompany public-private partnerships. When private investors have a role in the provision of public goods, they sometimes fail to fulfill the purpose of the underlying good. ${ }^{262}$ Regulatory capture may warp the public goals of the program. ${ }^{263}$ Therefore, the gains to be had through public-private partnerships should be balanced against the rising costs of monitoring conflicts of interests, enforcing

\footnotetext{
${ }^{259}$ GRUBER, supra note 99, at 197, 200-01. In some circumstances, the private sector has considered the broader benefits to free-riders and delivered a higher level of investment than reflects only their own receipts.

${ }^{260} \mathrm{Id}$. at 197.

${ }^{261} I d$. at $199-200$.

${ }^{262}$ KLEINBARD, supra note 223, at 280-82, 287.

${ }^{263} I d$. at 282 .
}

Pitt Tax Review | ISSN 1932-1821 (print) 1932-1996 (online) DOI 10.5195/taxreview.2019.105 | http://taxreview.law.pitt.edu 
program goals, and providing investors with a preferential return on their investment. ${ }^{264}$

One of the primary ways Congress has incentivized the mobilization of private capital investment in public and quasi-public goods, such as lowincome housing and renewable energy is through tax credits. ${ }^{265}$ Unfortunately, these transactions have been stymied by deal complexity and significant transaction costs, reducing the amount of the subsidy available to achieve program goals and to deliver to the targeted beneficiaries. ${ }^{266}$ Demand for tax credits has also waned over time. ${ }^{267}$ The Tax Cuts and Jobs Act of 2017 reduced corporate tax liability, ${ }^{268}$ which reduced demand for tax credits, resulting in declining aggregate investment in the projects tax credits were designed to support. ${ }^{269}$ Economic recessions may also undercut tax-credit

${ }^{264} \mathrm{Id}$.

${ }^{265}$ See, e.g., I.R.C. $\S \S 42 ; 45,48$.

${ }^{266}$ See Corianne Payton Scally et Al., Urban Inst., The Low-Income Housing TaX CREDit 13 (2018) (describing the ways deal complexity and transaction costs absorb between ten and twentyseven percent of a project's equity); Key Elements of the U.S. Tax System, TAX POL'Y CTR: BRIEFING BooK, https://www.taxpolicycenter.org/sites/default/files/briefing-book/key_elements_of_the_us_tax system_1.pdf (describing high transaction costs) (last visited Jan. 2, 2020).

${ }^{267}$ In 2001, Congress reduced the statutory corporate rates and hastened the recovery of capital investments through changes in accelerated depreciation provisions. See Alan J. Auerbach, Why Have Corporate Tax Revenues Declined? Another Look, 53 CESIFO ECON. STUD. 153, 159 (2007). As more businesses have chosen partnership, limited liability company, and S corporation forms, which receive pass-through taxation, the corporate income tax has declined. Id. at 163-64; see also CONG. BUDGET OfFice, Pub. No. 4298, TAXING Businesses Through the Individual Income TAX 1 (2012). Third, multinational corporations have been able to avoid the corporate tax through a number of mechanisms. In general, the U.S. corporate tax is paid only on foreign income that is repatriated to the United States; multinational corporations have avoided the tax by continuing to hold the cash overseas in foreign subsidiaries. Multinational corporations have shifted income to low-tax jurisdictions through transfer pricing and have used inversion strategies to obtain a foreign domicile and avoid U.S. corporate tax liability on their foreign earnings.

${ }^{268}$ See Tax Cuts and Job Act, Pub. L. No. 115-97, § 13001, 131 Stat. 2096 (2017) (reducing the top marginal corporate tax rate from thirty-five to twenty-one percent).

${ }^{269}$ In tax credit transactions, one dollar of investment results in one dollar of reduction in tax liability. While demand for tax credits was higher prior to the Tax Cuts and Jobs Act, with the price of the credit averaging between $\$ 1.05$ and $\$ 1.06$ in 2016 and 2017, upon the passage of the tax reform bill, prices for $\$ 1$ of tax credit dropped to approximately $\$ 0.92$, a twelve percent decline in value. See Affordable Housing Resource Center, LIHTC Pricing Trends January 2016-May 2019, NovoGRADAC, https://www .novoco.com/resource-centers/affordable-housing-tax-credits/data-tools/lihtc-pricing-trends (last visited Dec. 28, 2019) (Novogradac's low-income housing tax credit equity pricing chart is provided for general

Pitt Tax Review | ISSN 1932-1821 (print) 1932-1996 (online)

DOI 10.5195/taxreview.2019.105 | http://taxreview.law.pitt.edu 
financing transactions, since lower net revenues result in lower tax liability. ${ }^{270}$

Several scholars have argued in favor of a national infrastructure bank to provide loans for these types of large projects. ${ }^{271}$ If structured properly, a bank would be insulated from the current political demands of members of Congress and their constituents and donors, and independence would lend sufficient credibility to attract private capital. ${ }^{272}$ The investment and return horizons for large infrastructure projects are also compatible with the investment goals of pension funds and other institutional investors. ${ }^{273}$

\section{Manufacturing}

In addition to transforming the country's energy and transportation infrastructure, the Green New Deal includes plans to transform manufacturing. The primary source of tax support encouraging firms to acquire machinery, equipment, and other tangible assets include accelerated

information purposes only, with pricing based on letter of intent (LOI) pricing information syndicators and other parties shared with Novogradac).

${ }^{270}$ Tax credit investors have been comprised primarily of large corporations, banks, and insurance companies. These types of firms have predictable revenues that would justify acquiring tax credits to offset corporate income over longer periods. Following the Great Recession, the contraction and decline in the lending and insurance markets reduced the number of banks and insurance companies needing tax credits. See Paul Schwabe et al., Nat'L Renewable Energy lab., Renewable Energy Project FINANCING: IMPACTS OF THE FINANCIAL CRISIS AND FEDERAL LEGISLATION 3 (2009), http://www.nrel .gov/docs/fy09osti/44930.pdf.

${ }^{271}$ See, e.g., Thomas Marois, Transnat'l Inst., How Public Banks Can Help Finance a GREEN AND JUST ENERGY TRANSFORMATION (2017). Ed Kleinbard, a University of Southern California tax scholar and former Chief of Staff of the Joint Committee on Taxation suggests that an infrastructure bank could be modeled on the European Investment Bank. See KLEINBARD, supra note 223, at 282. Historically, the Reconstruction Finance Corporation played a similar role during World War II in mobilizing capital to transform the economy to meet wartime needs. See Hyman, supra note 97; see also Robert C. Hockett \& Saule T. Omarova, Private Wealth and Public Goods: A Case for A National Investment Authority, 43 J. CORP. L. 437, 457-63 (2018) (describing the organization and function of the Reconstruction Finance Corporation).

${ }^{272}$ KLEINBARD, supra note 223, at 287.

${ }^{273} \mathrm{Id}$.

Pitt Tax Review | ISSN 1932-1821 (print) 1932-1996 (online)

DOI 10.5195/taxreview.2019.105 | http://taxreview.law.pitt.edu 
depreciation ${ }^{274}$ and expensing. ${ }^{275}$ Certain amortization provisions incentivize the acquisition of intangible assets, such as software. ${ }^{276}$ Accelerated depreciation is a deferral mechanism, providing tax savings early in the useful life of the equipment. Accelerated depreciation effectively provides an interest-free loan to businesses to support their acquisition of equipment. While the modified accelerated cost recovery system has had a significant effect on debt-financed acquisitions of equipment since the 1980s, expensing under $\S 179$ and bonus depreciation under $\S 168(\mathrm{k})$ have had an even more substantial and wide-ranging effect. ${ }^{277}$ Congress's stated goal has been to stimulate the economy and simplify tax accounting for small businesses. ${ }^{278}$ While these subsidies do improve business cash flow in the short term, empirical studies indicate that they have not been effective in stimulating the economy. ${ }^{279}$ Nevertheless, the sooner a business recovers its investment in equipment, the sooner it may acquire new equipment to replace it.

When accelerated depreciation is combined with interest deductions on debt-financed acquisitions, the inflation-adjusted impact of deferred payments on the loan yield a negative income tax. ${ }^{280}$ In other words, the effective rate on debt-financed acquisitions of physical capital is a negative number, meaning that the federal government has been paying firms to acquire equipment. ${ }^{281}$ These effects are enhanced significantly by bonus depreciation. Through 2027, however, parties electing bonus depreciation

${ }^{274}$ I.R.C. $\S 168$.

${ }^{275} I d . \S \S 168(\mathrm{k}), 179$.

${ }^{276} I d . \S 197$.

${ }^{277}$ Jane G. Gravelle, Cong. ReSEARch Serv., R43432, Bonus Depreciation: ECONOMIC AND BUDGETARY ISSUES 3 (2014).

${ }^{278}$ GARy Guenther, CONG. ReSEARCH SERV., RL31852, SeCtion 179 AND BonUS DEPRECIATION EXPENSING ALLOWANCES: CURRENT LAW AND ISSUES FOR THE 114TH CONGRESS 10-14 (2015).

${ }^{279} I d$.

${ }^{280}$ GRAVELLE, supra note 277, at 10 (“Allowing accelerated depreciation whether by expensing or other methods causes a negative tax rate at the firm level, because the profit is taxed at the lower effective tax rate and the interest is deducted at the statutory rate. A differential in the tax rate of the firm and the creditor can also contribute to potentially negative tax rates with inflation, because the inflation portion of interest is deducted at the firm's rate and taxed at the individual's rate.").

${ }^{281} \mathrm{Id}$.

Pitt Tax Review | ISSN 1932-1821 (print) 1932-1996 (online)

DOI 10.5195/taxreview.2019.105 | http://taxreview.law.pitt.edu 
will face limitations on interest deductions. ${ }^{282}$ From 2018 through 2022, firms enjoy $100 \%$ bonus depreciation, allowing them to immediately expense acquisitions of tangible personal property. ${ }^{283}$ The bonus depreciation benefit then phases down from 2023 through $2027 .{ }^{284}$ These expensing provisions are likely to be one of the primary reasons revenues from the corporate income tax have declined significantly in the last two years. Perhaps, by limiting these types of expensing provisions to renewable energy infrastructure, zero-emissions transportation options, and green manufacturing equipment, the candidates may both improve the budget outlook and channel investment toward the country's transformation.

Several of the candidates have proposed to roll back some of the most expensive reforms in the Tax Cuts and Jobs Act. Roberta Mann identifies a number of international tax provisions in the Act that encourage investment in manufacturing abroad rather than in the United States. ${ }^{285}$ These provisions could be replaced with a sales-only formulary apportionment system to remove incentives to shift employees and facilities abroad. This would support the transportation and manufacturing sector in the United States. She also clarifies that carbon capture and storage has not lived up to its promise and identifies continuing subsidies for fossil fuels. ${ }^{286}$ If instead, policy makers were to remove support for fossil fuels and redirect funds toward renewable energy, the promise of the Green New Deal would be more quickly fulfilled.

\section{Ecology, Biodiversity, and Climate Resilience}

Many of the candidates plan to support biodiversity. Biodiversity enhances ecosystem productivity and resilience in the face of exogenous

\footnotetext{
${ }^{282}$ Note that the negative income tax effect has been addressed for the period between 2018 and 2027 by requiring those who elect to take bonus depreciation to forgo the deduction of interest on those acquisitions. I.R.C. § 163(j).

${ }^{283} \mathrm{Id} . \S 168(\mathrm{k})$.

${ }^{284} I d . \S 168(\mathrm{k})(6)$.

${ }^{285}$ Roberta Mann, Tax Policies for Clean Manufacturing: Implementing the Green New Deal, 17 PitT. TAX ReV. 25-30 (2020).

${ }^{286} I d$. at $32-36$.
}

Pitt Tax Review | ISSN 1932-1821 (print) 1932-1996 (online) DOI 10.5195/taxreview.2019.105 | http://taxreview.law.pitt.edu 
shocks. The United States has historically supported biodiversity through federal government ownership and management of land designated as national parks, national monuments, wilderness areas, and wildlife refuges. To encourage the private actors to engage in conservation, Congress developed a subsidy in the form of a federal tax deduction for conservation easements. ${ }^{287}$ Conservation easements were initially designed to preserve wildlife habitat, historic sites, and scenic vistas, and to preserve open space from development by granting a charity or governmental entity the right to restrict the use and development property. ${ }^{288}$ The charitable deduction for those who donate conservation easements has since become the primary tool for effectuating conservation goals. ${ }^{289}$ In terms of funding, the revenue lost from the deduction renders the program one of the largest federal environmental and land management programs in the United States. ${ }^{290}$

While forty million acres across the United States have been protected with permanent conservation easements, it is not clear that the lands being preserved actually serve ecological goals. ${ }^{291}$ First, the charitable deduction for conservation easements has become a wasteful tax expenditure, as donors and donees have conspired to overvalue donated land. ${ }^{292}$ Second, the easements often cover land that has little or no public benefit; conservation easements now cover golf courses in gated residential communities and the community areas in suburban subdivisions. ${ }^{293}$ Third, even when the easements do protect valuable ecological resources, the local government agencies and nonprofit organizations responsible for monitoring and enforcing the easements fail to do so, undermining the goal of the subsidy. ${ }^{294}$ Conservation easements also compete with other conservation efforts, such

${ }^{287}$ See I.R.C. $\S 170$.

${ }^{288}$ Nancy A. McLaughlin, Tax Incentives for Conservation Easement Donations: Learning from the U.S. Experience, in TAX LAW AND THE ENVIRONMENT, supra note 209, at 219, 219.

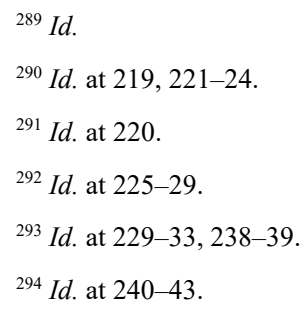

Pitt Tax Review | ISSN 1932-1821 (print) 1932-1996 (online) DOI 10.5195/taxreview.2019.105 | http://taxreview.law.pitt.edu 
as regulatory controls and land acquisition efforts, undermining ecosystem protection and biodiversity preservation efforts. ${ }^{295}$

Finally, climate change and other dynamic landscape changes are now drawing into question whether permanent conservation easements can accommodate the adaption needed to respond to natural disasters and the other effects of climate change. ${ }^{296}$ While conservationists may address some of these issues through changes in the way they draft their easements to provide the needed stringency and flexibility that will be required to counter the effects of climate change, ${ }^{297}$ a redirection of the subsidy program could potentially bolster those efforts. The subsidy requires reform to prevent waste and misdirection of important resources. ${ }^{298}$

\section{E. Reaching People Through Tax Support}

Much of the Green New Deal focuses on delivering benefits and support to Americans who have been marginalized or who will be most affected by the implementation of climate change policy. Policy makers should consider certain parameters in structuring a tax subsidy if they hope to reach low- and moderate-income taxpayers. The income tax has a system of graduated rates for ordinary income. Currently the rates are ten, twelve, twenty-two, twentyfour, thirty-two, thirty-five, and thirty-seven percent on ordinary income. ${ }^{299}$ As taxpayers earn more income, their last earnings for the year are taxed at higher marginal rates. ${ }^{300}$ After applying the standard deduction, which is $\$ 12,200$ for an unmarried individual in 2019 , a single taxpayer will pay ten percent on their first $\$ 9,700$ dollars of taxable income, twelve percent on their next $\$ 29,775$ dollars of taxable income, twenty-two percent on their next

\footnotetext{
${ }^{295} \mathrm{Id}$. at 243.

296 Jessica Owley et al., Climate Change Challenges for Land Conservation: Rethinking Conservation Easements, Strategies, and Tools, 95 DENV. L. REV. 727, 727 (2018).

${ }^{297}$ Id. at 771-79.

${ }^{298}$ McLaughlin, supra note 288, at 243-44.

${ }^{299}$ I.R.C. § 1(j)(2); Rev. Proc. 2018-57, 2018-49 I.R.B. 827, 830-31.

${ }^{300}$ I.R.C. $\S 1(\mathrm{j})(2)$. Generally, employers will calculate the annual salary or wages for their employees and average all of the taxes that are likely to be owed on that income and deduct that sum for each paycheck, so that the employee may maintain steady take-home pay.
}

Pitt Tax Review | ISSN 1932-1821 (print) 1932-1996 (online) DOI 10.5195/taxreview.2019.105 | http://taxreview.law.pitt.edu 
$\$ 44,725$ dollars of taxable income, twenty-four percent on their next $\$ 76,525$ and so on. ${ }^{301}$ To determine the dollar value of an exclusion, exemption, or deduction from income, one multiplies the amount of the subsidy by the marginal tax rate of the taxpayer. The higher the taxpayer's income, the higher his marginal tax rate. The higher the taxpayer's marginal tax rate, the higher the benefits are from a tax exclusion, exemption, or deduction.

For example, Adam, an individual making gross income of $\$ 20,000$, after deducting the standard deduction would have $\$ 7,800$ in taxable income, and would pay $\$ 780$ in taxes. A deduction of $\$ 1,000$ would reduce his adjusted gross income by $\$ 1,000 .^{302} \mathrm{He}$ would have $\$ 680$ in tax liability, resulting in tax savings of $\$ 100$. On the other hand, Zev, an individual earning $\$ 100,000$ in gross income would have $\$ 87,800$ in taxable income after applying the standard deduction and pay $\$ 15,247$ in taxes. A deduction of $\$ 1,000$ would reduce Zev's income by $\$ 1,000$, leaving him with $\$ 86,800$ in taxable income after applying the standard deduction. Zev's tax liability would be $\$ 15,007$ and his tax savings from the same deduction as Adam $(\$ 1,000)$ would be $\$ 240$.

In contrast, tax credits apply dollar-for-dollar to reduce a taxpayer's tax liability. However, if the tax credits are not fully refundable, a lower-income household with net tax liability that does not exceed the tax credit will not enjoy the full benefit of the credit. ${ }^{303}$ Only refundable tax credits carry the same value across the income strata for all taxpayers. Therefore, policy makers considering delivering benefits through the income tax should structure those benefits as refundable tax credits if they want to reach all taxpayers on an equal basis.

Legislators may wonder why they should deliver subsidies through the income tax when they can deliver a grant, loan, or other subsidy through an annual budget allocation. The answer is that the tax code is a good place to

\footnotetext{
${ }^{301}$ Rev. Proc. 2018-57, 2018-49 I.R.B. 827, 830.

${ }^{302} \mathrm{Id}$. This assumes that the deduction is an above-the-line deduction used to calculate adjusted gross income that all taxpayers may take under $\S 62$. Many below-the-line deductions that taxpayers may take as an alternative to the standard deduction, which are generally allowed in calculating taxable income have been suspended through 2025.

${ }^{303}$ See Lily L. Batchelder et al., Efficiency and Tax Incentive: The Case for Refundable Tax Credits, 59 STAN. L. REV. 23, 53-54 (2006) (discussing the U.S. tax system and refundable tax credits).
}

Pitt Tax Review | ISSN 1932-1821 (print) 1932-1996 (online) DOI 10.5195/taxreview.2019.105 | http://taxreview.law.pitt.edu 
hide treasure. The complexity of the income tax and its perennial nature as permanent legislation renders its giveaways to special interests largely invisible and resistant to attack. ${ }^{304}$ Historically, proponents of fossil fuels have hidden substantial subsidies in the tax code, where they have remained undisturbed for over one hundred years. ${ }^{305}$ While some features, such as tax credits, are typically appended to the front of the tax code and are time limited, others have become permanent by virtue of their support by special interests and by their being structured to look like, and located in the same place as, the "normal" provisions of the income tax used to measure income. ${ }^{306}$ The proponents of the Green New Deal anticipate that their programs will be in place for ten years, and that that ten-year budgetary period is sufficient to transform the economy while limiting its effects on the deficit and the federal debt. However, if they want to create lasting legislation, they should look to the income tax. ${ }^{307}$

\section{CONCLUSION}

The Green New Deal is a welcome addition to the national discussion to address climate change, pollution, the decline in the availability of jobs and opportunities for all Americans. All of the Democratic presidential candidates who have embraced the Green New Deal have generated innovative ideas that can reduce the national and international impacts of climate change, green the U.S. economy, and provide well-paying jobs while building infrastructure that will ensure the nation's prosperity well into the next century. This Article has reviewed the means and methods by which the candidates can achieve these goals.

There are several key takeaways. First, a greenhouse gas tax is probably the most efficient, most transparent, and simplest method for addressing climate change. Second, whether policy makers employ command-andcontrol regulation under the Clean Air Act or impose a carbon tax, any efforts to address the causes of climate change will affect the finances of all

\footnotetext{
${ }^{304}$ Stanley S. Surrey, Pathways to TAX REForm: The Concept of TAX EXPENDitures 6, 92-94 (1973).

${ }^{305}$ Tracey M. Roberts, Picking Winners and Losers: A Structural Examination of Tax Subsidies to the Energy Industry, 41 COLUM. J. ENVTL. L. 63, 64-68, 74-93 (2016).

${ }^{306}$ Id. at $116-19$.

${ }^{307}$ See Rebecca M. Kysar, Lasting Legislation, 159 U. PA. L. REV. 1007 (2011).
} 
Americans. The most efficient way to offset these impacts for low- and middle-income Americans is to deliver a lump-sum rebate, preferably in the form of a refundable tax credit delivered through the federal income tax. The Internal Revenue Service already has the institutional expertise and infrastructure to measure income and deliver substantial monetary benefits to low- and moderate-income households.

Third, taxing negative externalities is more efficient and possibly more effective than subsidizing substitutes. Providing subsidies for less polluting technologies and activities requires legislators to pick and choose what they are going to subsidize. Legislators are prone to error. On the other hand, taxes on fossil fuels and other forms of pollution are generally passed through to consumers in the prices of the goods and services they purchase. As a result, green options become more attractive because they are less expensive. Markets aggregate the individual wisdom and experience of everyone buying and selling in the consumer sphere (for electric cars, for weatherization materials, for modular homes). When policy makers tax pollution, the aggregate public response serves as a form of collective wisdom to pick the best nonpolluting substitutes.

Fourth, subsidizing positive externalities and public goods is more efficient and possibly more effective than having the federal government provide them in their entirety. Using solely federal funds to create large infrastructure projects may deter private capital from making these important investments. Subsidies, by reducing risk, can encourage private investment and make federal funds go farther. However, the use of federal tax credits to encourage private capital investment is ill-advised. The Tax Cuts and Jobs Act reduced corporate tax liability significantly. It has therefore undermined demand for tax credits and will reduce aggregate investment in the projects the tax credits have been designed to support. Tax-credit-based equity investment transactions also generate very high transaction costs that reduce the value of the capital investment to the projects. Private investment in large infrastructure projects would be better supported through debt financing, including the issuance of bonds, loans, and loan guarantees. Pension funds and other institutional investors have historically made investments that produce returns over long periods with limited risk; these goals match the timing and risk profiles for large infrastructure projects, rendering them an attractive investment option.

Tax credits can be effective as direct subsidies to individuals and businesses that are generating positive externalities; they may be used effectively to encourage sustainable agriculture practices, soil-based carbon

Pitt Tax Review | ISSN 1932-1821 (print) 1932-1996 (online)

DOI 10.5195/taxreview.2019.105 | http://taxreview.law.pitt.edu 
sequestration, preservation of natural habitat, and support for biodiversity. Finally, any tax benefit to be delivered to the general public should be structured as a refundable tax credit. Tax exclusions, exemptions, and deductions are all regressive and provide greater value to taxpayers with higher levels of income. Only a refundable tax credit will extend the same level of financial benefit to every eligible U.S. resident regardless of income or lack thereof.

Policy makers have a broad array of tools available to effectuate the Green New Deal. Taxes and tax subsidies provide attractive policy options enhancing both efficiency and equity when structured and deployed with some planning and care. 
